Document downloaded from:

http://hdl.handle.net/10251/59989

This paper must be cited as:

Portoles, J.; Romero, ML.; Bonet Senach, JL.; Filippou, F. (2011). Experimental study of high strength concrete-filled circular tubular columns under eccentric loading. Journal of Constructional Steel Research. 67(4):623-633. doi:10.1016/j.jcsr.2010.11.017.

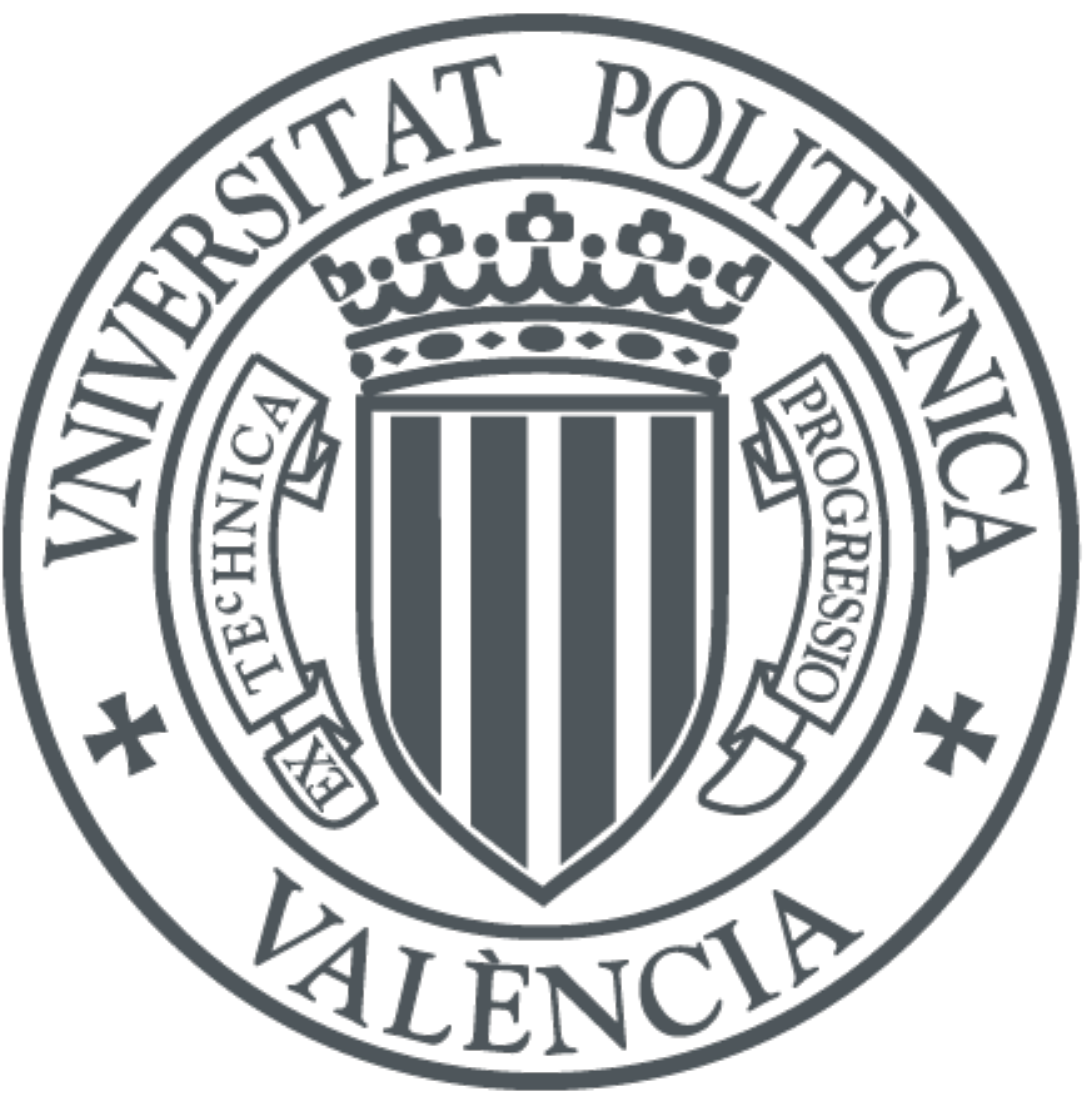

The final publication is available at

http://dx.doi.org/10.1016/j.jcsr.2010.11.017

Copyright Elsevier

Additional Information 
Portolés J1, Romero ML*, Bonet JL and Filippou FC, Experimental study of high strength concrete-filled circular tubular columns under eccentric loading, Journal of Constructional Steel Research 2011; 67 (4) : 623-633.

\title{
Experimental study of high strength concrete-filled circular tubular columns under eccentric loading
}

\author{
J.M. Portolés $^{\mathrm{a}}$, M.L. Romero ${ }^{\mathrm{b}}$, J.L. Bonet ${ }^{\mathrm{b}}$ and F.C. Filippou ${ }^{\mathrm{c}}$ \\ a Department of Mechanical Engineering and Construction, Universitat Jaume I, \\ Castellón, Spain \\ b Instituto de Ciencia y Tecnología del Hormigón (ICITECH). Universidad \\ Politécnica de Valencia, Spain \\ c Civil and Environmental Engineering Department. University of California at \\ Berkeley, USA
}

\begin{abstract}
The paper describes 37 tests conducted on slender circular tubular columns filled with normal and high strength concrete subjected to eccentric axial load. The test parameters were the nominal strength of concrete $(30,70$ and $90 \mathrm{MPa})$, the diameter to thickness ratio $\mathrm{D} / \mathrm{t}$, the eccentricity ratio e/D and the column slenderness (L/D). The experimental ultimate load of each test was compared with the design loads from Eurocode 4, which limits the strength of concrete up to 50MPa. The aim of the paper is to establish the advisability of the use of high strength concretes as opposed to that of normal strength concretes by comparing three performance indexes: concrete contribution ratio, strength index and ductility index. The results show for the limited cases analyzed that the use of high strength concrete for slender composite columns is interesting since this achieves ductile behavior despite the increase in load-carrying capacity is not greatly enhanced.
\end{abstract}

Keywords: composite column, concrete-filled tubular columns, high strength concrete, buckling

*Corresponding author: Tel: +34-963877007(ext: 76742) Fax: +34-963879679,

E-mail address: mromero@mes.upv.es 
Portolés Jl, Romero ML*, Bonet JL and Filippou FC, Experimental study of high strength concrete-filled circular tubular columns under eccentric loading, Journal of Constructional Steel Research 2011; 67 (4) : 623-633.

\section{INTRODUCTION}

In recent years there has been an increase in the use of concrete-filled tubular columns (CFT) due to its high stiffness, ductility and fire resistance. Moreover, the use of high strength concrete (HSC) has become more frequent due to the advances in technology, mainly those affecting elements subjected to high compression. Both these technologies combined fit the requirements for columns in multi-story buildings because a substantial reduction of the cross section is obtained. However the study of the influence of the high strength concrete has concentrated mainly on short columns with axial load rather than slender columns subjected to eccentric loading.

The design codes of each country provide simplified methods for composite columns, but are generally limited to the use of concrete with a cylinder strength lower than 50-60 MPa, as in the case of Eurocode 4 (EC4) [1], and hence, need to be revised. This is crucial given that in the practical design of a column in a building the axial load, eccentricity and height of the storey are fixed. In this situation if HSC is used, as opposed to normal strength concrete (NSC), the section is reduced and the slenderness increased, and the element presents greater buckling.

Recently, some papers have been published reviewing the latest technology in composite concrete-filled tubular columns, [2] , [3] , [4]. The conclusion reached was that further experimental tests for HSC-filled columns are necessary.

Gourley et al [4] in particular, stated that as high strength concrete is characterized by low dilatation, a substantial confinement effect is not produced. However other authors do not totally agree with this statement because the confinement effect relates not only to the increment of the maximum load but also to the post-peak behavior. 
Portolés Jl, Romero ML*, Bonet JL and Filippou FC, Experimental study of high strength concrete-filled circular tubular columns under eccentric loading, Journal of Constructional Steel Research 2011; 67 (4) : 623-633.

Through numerical and experimental studies Johansson and Gylltoft [5],[6], and Zeghiche and Chaoui [7], have demonstrated that it is possible to use high-strength concretes and still achieve structural ductile behavior. However, if the aim is to obtain the same ductility, a thicker steel tube is needed for HSC as opposed to normal strength concrete.

If the column is slender and is subjected to an eccentric load it seems clear that the increasing strain gradient of the cross-section and increase in flexure are to the detriment of any improvement in the concrete strength due to the confinement effect [5] . O'Shea and Bridge[8] however stated that when eccentricity is increased in short columns ductility is also improved.

This statement needs to be amplified for slender columns, as there are not many studies on high performance materials for CFTs, focusing on the overall buckling. Han [9] studied tubular columns with high slenderness ratio but with normal strength concrete, concluding that strength of the concrete has very little influence on the ultimate capacity because the failure load is governed by the flexural rigidity.

One interesting point of view was presented some time ago by Shakir-Khalil and Mouli [10] who discussed the gain which could be made by using concrete-filled columns rather than bare steel columns. They argued that the increase in the carrying capacity of the column, resulting from being filled with plain concrete depends on the characteristics of the steel and concrete used, on the size of the steel section, on the column length and also on the eccentricities.

Some of the most relevant contributions to experimental knowledge on CFTs have been published over the last few years. Sakino et al.[11] and Fujimoto et al [12] performed more than 100 tests, some of them using HSC, but with a maximum length of 
Portolés Jl, Romero ML*, Bonet JL and Filippou FC, Experimental study of high strength concrete-filled circular tubular columns under eccentric loading, Journal of Constructional Steel Research 2011; 67 (4) : 623-633.

$1 \mathrm{~m}$. They concluded that the use of HSC reduces the ductility of circular CFT, however this can be improved in two ways by using small values of $\mathrm{D} / \mathrm{t}$ or increasing the strength of the steel $\left(f_{\mathrm{yk}}\right)$.

Grauers [13] performed experimental tests on 23 short columns and 23 slender columns, and concluded that the methods of the different codes were valid but that the research should be extended in order to analyze the effect of other parameters. She obtained better ductile behavior introducing a small eccentricity. Later, Bergman [14] studied the confinement mainly for normal strength concrete and partially for high-strength concrete, but applying only axial load and not eccentricity. He observed a non-ductile behavior once the maximum load was reached.

Rangan and Joyce [15] and Kilpatrick and Rangan [16] presented experimental results from 9 columns for uniaxial bending and 24 columns for double curvature bending, although their tests were limited up to $64 \mathrm{MPa}$ of concrete.

Liu et al. [17] experimentally compared the capacity of 22 rectangular sections with the different codes (AISC, ACI, EC4), concluding that the Eurocode 4 was not totally safe while other codes over-designed the sections.

Varma et al. [18] studied the behavior of the square tubular columns asserting that the curvature ductility of strength square CFT beam-columns (1.5 meters) decreased significantly with an increase in either the axial load level or the $b / t$ ratio of the steel tube.

Recently Yu et al. [19] published the results of research on circular, square, short and long CFTs filled with high performance self-consolidating concrete. The results were in agreement using different design codes. 
Portolés Jl, Romero ML*, Bonet JL and Filippou FC, Experimental study of high strength concrete-filled circular tubular columns under eccentric loading, Journal of Constructional Steel Research 2011; 67 (4) : 623-633.

Zeghiche and Chaoui [7] conducted tests on 27 CFTs. The test parameters were slenderness, eccentricity and single and double curvature. The results were compared with EC4 provisions, resulting on the unsafe side for double curvature. They stated that more numerical and experimental tests should be performed to check the validity of the buckling design methods of Eurocode 4 for high strength concrete for single and double curvature. They also stated that the increase of concrete core strength is only effective for shorter columns and decreases with $\mathrm{L} / \mathrm{D}$. Their tests did not vary the $\mathrm{D} / \mathrm{t}$ ratio which is one of the parameters that can improve the ductile behavior.

Giakomelis and Lam [20] affirmed that for stub columns under axial loads Eurocode 4 gives the best estimation both for normal and high-strength concrete. This statement was extended by Goode [21] who compiled the results of numerous tests, and compared them with Eurocode 4 (EC4) provisions reaching the conclusion that although for circular sections it could be extended to $75 \mathrm{MPa}$, more tests are needed mainly for long circular tubular columns in combination with a bending moment.

In conclusion an analysis of the bibliography makes it clear that the use of HSC in concrete-filled tubular columns does not offer the same improvement as the use of NSC in composite behavior but that by using the correct combination of the parameters of the section $\left(D / t, f_{y k}, f_{c k}\right)$ with the correct combination of the parameters that define the element (L/D and e/D) it is possible to achieve ductile behavior. One aim of this paper is to advance in the knowledge of HSC for concrete-filled tubular columns.

This paper presents the results of the experimental study carried out on circular concrete-filled tubular columns under eccentric compression loading and single curvature bending. In these tests the load eccentricity at the ends is fixed and the maximum axial load of the column is evaluated. Different performance indexes were 
Portolés Jl, Romero ML*, Bonet JL and Filippou FC, Experimental study of high strength concrete-filled circular tubular columns under eccentric loading, Journal of Constructional Steel Research 2011; 67 (4) : 623-633.

used to study the effects of the main variables on the load-carrying capacity and ductility. The results were compared with the design load obtained from Eurocode 4 in order to analyze the applicability of the code for high strength concrete. These experimental results are part of a research program that studies the effect of high strength concrete on buckling. It consists of three main parts: an experimental study, a one-dimensional numerical model, and a three-dimensional model.

\section{EXPERIMENTAL PROGRAM}

In this experimental program thirty-seven tests were carried out on normal and high strength concrete columns. These tests were designed to investigate the effects of four main parameters on their behavior: slenderness (L/D), diameter to thickness ratio (D/t), strength of concrete $\left(f_{c k}\right)$ and eccentricity $\left(e_{0}\right)$. The ranges of these parameters were selected according to ranges of construction practice, in order to include cases of high strength concretes and high eccentricities as well, where we noted there was a lack of experimental research. Table 1 summarizes the experimental data. The column lengths were $2135 \mathrm{~mm}$ and $3135 \mathrm{~mm}$ because although the lengths of the tubes were $2 \mathrm{~m}$ and 3 $\mathrm{m}$, the distance between the hinges needs to add the special assembly length. The nominal cross-section of the circular tubes (diameter " $\mathrm{D}$ " $\times$ thickness "t") were $100 \times$ $3 \mathrm{~mm}, 100 \times 5 \mathrm{~mm}, 125 \times 5 \mathrm{~mm}$, and $160 \times 6 \mathrm{~mm}$. The thicknesses of the tubes were selected in order to avoid local buckling following Eurocode 4. The nominal strength of concrete varied from 30,70 to $90 \mathrm{MPa}$. In some cases empty tests were included as a reference. The axial load was applied with the same eccentricity at both ends with a value of 20 or $50 \mathrm{~mm}$. All of the tests were performed in the laboratory of the Department of Mechanical Engineering and Construction of the Universitat Jaume I in Castellón, Spain. The nomenclature followed in the tests was: 
Portolés J1, Romero ML*, Bonet JL and Filippou FC, Experimental study of high strength concrete-filled circular tubular columns under eccentric loading, Journal of Constructional Steel Research 2011; 67 (4) : 623-633.

CXXX-T-L-FF-EE-1 (i.e. C125-5-3-90-50-1), where C stands for circular, XXX is the nominal diameter in $\mathrm{mm}$, " $\mathrm{T}$ " the thickness in $\mathrm{mm}, \mathrm{L}$ the nominal length in meters, FF the nominal concrete strength in $\mathrm{MPa}$, and $\mathrm{EE}$ is the applied eccentricity.

\subsection{Material properties}

The cold formed and welded steel tubes were supplied by a manufacturer. The steel grade was S275JR and the real strength $\left(f_{y}\right)$ of the empty tubes was obtained by coupon test. The modulus of elasticity 'Es' of the steel was set by European standards with a value of $210 \mathrm{GPa}$.

All columns were cast using concrete batched in the laboratory. Table 2 summarizes the mix proportions of the batches for the nominal concrete strengths of 30,70 and 90 $\mathrm{MPa}$. The concrete compressive strength ' $\mathrm{f}_{\mathrm{c}}$ ' was determined from both the $150 \times 300$ $\mathrm{mm}$ cylinder and the $100 \mathrm{~mm}$ cube using standard tests. The strength of the cubic samples was translated to the cylindrical equivalent using Eurocode 2. All samples were tested on the same day as the column test. Table 1 lists the values of $f_{y k}$ and $f_{c k}$ obtained.

\subsection{Fabrication of columns}

A $350 \mathrm{~mm} \times 350 \mathrm{~mm} \times 10 \mathrm{~mm}$ plate was welded to the bottom of each empty steel tube to facilitate the casting of the fresh concrete and to join the element to the pinned support assembly. The elements were then cast in an inclined position for less air trapping. The concrete was vibrated every $0.5 \mathrm{~m}$ with a needle vibrator. Finally the specimen was placed in a vertical position and covered with wet cloth. Prior to the test, the columns were closed off with another similar welded plate to ensure perfect contact between the plates and the steel and concrete core. 
Portolés Jl, Romero ML*, Bonet JL and Filippou FC, Experimental study of high strength concrete-filled circular tubular columns under eccentric loading, Journal of Constructional Steel Research 2011; 67 (4) : 623-633.

\subsection{Test Setup and procedure}

Figure 1 presents a general overview of the tests. Depending on the length, some of the columns were tested in the vertical $2000 \mathrm{kN}$ setup (Figure 1a), and others in the horizontal $5000 \mathrm{kN}$ setup (Figure 1b). The eccentricity of the applied compressive load was equal at both ends, so the columns were subjected to single curvature bending. It was necessary to build up special assemblies at the pinned ends to apply the load eccentrically. Five LVDT's were used to symmetrically measure the deflection of the column at mid length $(0.5 \mathrm{~L})$ and also at four additional levels $(0.25 \mathrm{~L}, 0.37 \mathrm{~L}, 0.625 \mathrm{~L}$, $0.75 \mathrm{~L}$ ). The strains were measured at the central section using electrical strain gauges, which recorded the deformation in two perpendicular directions: longitudinal and circumferential, and three locations $0^{\circ}, 90^{\circ}$, and $180^{\circ}$ degrees, as can be seen in Figure 1.

Once the specimen was put in place, it was tested in displacement control in order to measure post-peak behavior.

\section{ANALYSIS OF THE RESULTS}

\subsection{Force-displacement.}

Figure 2 presents the force-displacement curves for the test organized by series.

Figures 2.a to 2.d are the cases with a diameter of $100 \mathrm{~mm}$, but varying the other variables. In these tests, the general tendency of the curves is as expected: when the eccentricity or the length is increased the maximum load is reduced. In addition, when the thickness of the tube or the strength of concrete is increased the load is increased, although this latest increment is lower when the high-strength concrete is introduced.

However some issues need to be emphasized. As can be inferred, the columns with lower length (100-3-2 and C100-5-2 series) have less ductility than the equivalent longer series (C100-3-3 and C100-5-3). It is also interesting to observe the series $3 \mathrm{~mm}$ 
Portolés Jl, Romero ML*, Bonet JL and Filippou FC, Experimental study of high strength concrete-filled circular tubular columns under eccentric loading, Journal of Constructional Steel Research 2011; 67 (4) : 623-633.

thick and 3 meters long (C100-3-3 series), where there is almost no difference between

a $71 \mathrm{MPa}$ concrete and 94.6 MPa one. It seems to indicate that failure is due to the steel

tube and that increasing the concrete strength would have no effect.

For the cases of more slender columns with higher eccentricity, it can be demonstrated that expensive HSC is no more useful than NSC. This statement will be discussed in the following sections in more detail.

Again, if the results of Figure 2.d, Figure 2.e and Figure 2.f are compared, it can be deduced that by maintaining the length $(\mathrm{L}=3 \mathrm{~m})$, the concrete contribution appears to decrease with the $\mathrm{D} / \mathrm{t} \operatorname{ratio}(20$ for $\mathrm{C} 100.5,25$ for $\mathrm{C} 125.5$ and 28.09 for $\mathrm{C} 160.6$ respectively), which implies that enhancement is higher for massive sections (lower $\mathrm{D} / \mathrm{t})$.

\subsection{Failure mode.}

It was found that the typical failure mode for all the tested specimens was the overall buckling mode and not the material failure. This can be seen in Figure 3.a where the axial load and the total bending moment (including the eccentricity and the displacement) in the mid-span section are presented. In this figure when the maximum load is reached the bending moment still increases. This behavior can also be shown in an interaction diagram, Figure 3.b, where the axial load versus the bending moment is displayed next to the interaction diagram obtained with Eurocode 4[1]. In this, the experimental $\mathrm{N}-\mathrm{M}$ curve does not intersect the interaction diagram in the maximum load. In this graph the method proposed by EC4 is also shown in dashed lines.

\section{3.- Local behavior.}


Portolés Jl, Romero ML*, Bonet JL and Filippou FC, Experimental study of high strength concrete-filled circular tubular columns under eccentric loading, Journal of Constructional Steel Research 2011; 67 (4) : 623-633.

One of the objectives of the project was to advance in the knowledge of the local behavior of composite sections when subjected to axial load and bending moment. This is studied by presenting the deformations obtained with the strain gauges.

Figure 4 presents the longitudinal deformation at the left $\left(\varepsilon_{\mathrm{L}}\right)$ and the circumferential deformation at the right $\left(\varepsilon_{\mathrm{C}}\right)$ of three different points of the section: on the compression side $\left(0^{\circ}\right)$ on the tension side $\left(180^{\circ}\right)$ and on a point in between, over the symmetry axis $\left(90^{\circ}\right)$

It can be shown that the relationship between the circumferential strain at the point of maximum compression $\varepsilon_{\mathrm{C} 0}$, figure $4 . \mathrm{b}$, and the longitudinal strain at the same point $\varepsilon_{\mathrm{L} 0}$ in figure 4.a, is almost at a constant value of ' -0.3 ' (the steel Poisson ratio) until the deformation reaches a value close to $2000 \mu \varepsilon$, which means that there is no composite action up to the yielding of the steel section. This ratio changes after this point but only appears as a notable tridimensional behavior in the descending branch (which affects the ductility).

It can also be shown that the longitudinal deformation corresponding to the maximum load at the tension point $\left(180^{\circ}\right), \varepsilon_{\mathrm{L} 180}$ in figure 4.e, depends largely on the eccentricity and to a lesser extent on the strength of the concrete. For larger eccentricities and higher concretes the deformation increases. This means that if there is a bigger bending moment the neutral axis is close to the centre and a greater part of the section is under tension. Also, if there is a greater area working under tension the compressed area of concrete has greater relevance and the maximum load is reached when the concrete is crushed. It can be seen that the deformation ( $\varepsilon_{\mathrm{L} 0}$ in figure $\left.4 . \mathrm{a}\right)$ is similar to the deformation corresponding to the maximum strength set out in Eurocode 4, and increases with the strength. This has also been verified with the longitudinal 
Portolés Jl, Romero ML*, Bonet JL and Filippou FC, Experimental study of high strength concrete-filled circular tubular columns under eccentric loading, Journal of Constructional Steel Research 2011; 67 (4) : 623-633.

deformation of the $90^{\circ}\left(\varepsilon_{\mathrm{L} 90}\right.$ in figure 4.c), because if the neutral axis is closer to the centre of the section it has to be lower for larger eccentricities and higher concretes.

An additional commentary can be made on the three circumferential strains $\left(\varepsilon_{\mathrm{C} 0}\right.$, $\varepsilon_{\mathrm{C} 90}$, and $\left.\varepsilon_{\mathrm{C} 180}\right)$ because they represented the way that the section changed shape. As stated by Gourley et al [4], a circular section becomes circular if the load is applied concentrically but becomes elliptical or ovoidal if the load is applied with eccentricity. This can be seen in the case of these strains since they change value and also sign, meaning that the final shape of the section will be very complex and obtaining a distribution of the lateral confinement will be not an easy task.

\section{PERFORMANCE INDEXES}

\subsection{Concrete Contribution Ratio (CCR).}

One of the objectives of this paper was to establish the importance of the use of high strength concretes compared with that of normal strength concretes. To do so, the concrete contribution ratio (CCR) is defined as the ratio between the maximum load of the composite column and the empty hollow steel member:

$$
\mathrm{CCR}=\frac{\mathrm{N}_{\text {max,exp }}}{\mathrm{N}_{\text {max,hollow }}}
$$

As there are too many variables that affect this index, three combined variables which mix the main parameters affecting the test were selected: section behavior (confinement index, $\theta$ ), relative slenderness $(\lambda)$ and the strength of concrete ' $f_{\mathrm{ck}}$ '.

The confinement index $\theta$ was used by different authors and is defined as: 
Portolés Jl, Romero ML*, Bonet JL and Filippou FC, Experimental study of high strength concrete-filled circular tubular columns under eccentric loading, Journal of Constructional Steel Research 2011; 67 (4) : 623-633.

$$
\theta=\frac{A_{s} f_{y}}{A_{c} f_{c k}}
$$

This is a ratio between the maximum capacity of steel and concrete, and represents the mechanical slenderness of the section. For short columns it is directly related to the confinement obtained.

The relative slenderness $\lambda$ defined in Eurocode 4 is used instead of L/D because it includes not only the geometric but also the material properties:

$$
\lambda=\sqrt{\frac{N_{p l}}{N_{c r}}}=\sqrt{\frac{A_{c} f_{c k}+A_{s} f_{y}}{\frac{\pi^{2} E I}{L_{k}^{2}}}}
$$

Figure 5 presents the values of the concrete contribution ratio (CCR) in terms of $f_{c k}$, $\theta$ and $\lambda$ for the experiments with a diameter $\mathrm{D}=100 \mathrm{~mm}$. It denotes the gain which could be made by using concrete-filled columns rather than bare steel columns. For those cases where there was no experimental value for the empty tube, a numerical simulation was adopted. Table 3 also summarizes the performance indexes.

Figure 5.a shows that the benefit increases with the strength of concrete but this increment is not as notable in the case of higher concrete. In most of cases there is no reason to increase the concrete from 70 to $90 \mathrm{MPa}$. The higher $\mathrm{CCR}$ is obtained for shorter columns with lower eccentricity, and the opposite happens when the eccentricity or the length is higher.

However, the same conclusions were not achieved for a thicker tube, Figure 5.b, where there was more steel working in the section. Surprisingly, the longer tubes have higher CCR. The CCR values for the cases with $\mathrm{L}=2 \mathrm{~m}$ in Figure $5 . \mathrm{b}(\mathrm{D} / \mathrm{t}=20)$ are lower compared with the values of Figure 5.a $(\mathrm{D} / \mathrm{t}=33.3)$, while for the cases where $\mathrm{L}=3 \mathrm{~m}$ the CCR is higher for thicker tubes (100.5 series) than for thinner tubes (100.3 series). 
Portolés Jl, Romero ML*, Bonet JL and Filippou FC, Experimental study of high strength concrete-filled circular tubular columns under eccentric loading, Journal of Constructional Steel Research 2011; 67 (4) : 623-633.

Similar conclusions were obtained from Figure 5.e and Figure 5.f where the CCR is presented in terms of the relative slenderness $\lambda$. To understand these graphs it is important to bear in mind that with the same hollow tube filled with different concretes, the one with higher-strength concrete has higher relative slenderness.

Figure 5.c and Figure 5.d show the concrete contribution ratio in terms of the socalled confinement index $\theta$. In these cases the tubes with higher concretes have lower $\theta$ values. This tendency predicts the same behavior as previously depicted. The only point of interest issue is that for the 100.3 series most of the values of $\theta$ are less than one while these are higher than one for the 100.5 series. Some authors [6] have pointed out that there is a different behavior when the confinement index exceeds the value of one. This is probably the reason why the CCR follows a different trend in the 100.3 series and 100.5 series.

That is, the tendency of the CCR is a combination between the relative slenderness $\lambda$ (which includes the $f_{\text {ck }}$ ) and the confinement index, but more experimental cases or a numerical parametrical study are needed to reach a reliable conclusion.

\section{2.- Strength Index (SI).}

The strength index is defined as:

$$
\mathrm{SI}=\frac{\mathrm{N}_{\text {max }}}{\mathrm{N}_{p l, \mathrm{Rd}}}=\frac{\mathrm{N}_{\text {max }}}{\mathrm{A}_{\mathrm{c}} \mathrm{f}_{\mathrm{ck}}+\mathrm{A}_{\mathrm{s}} \mathrm{f}_{\mathrm{y}}}
$$

It compares the maximum load of the slender column with the resistance of the composite cross section (without any confinement effect). It is similar to the buckling reduction factor $(\chi)$ for a member in axial compression without eccentricity from Eurocode 4, but it cannot be linked to any buckling curves. 
Portolés J1, Romero ML*, Bonet JL and Filippou FC, Experimental study of high strength concrete-filled circular tubular columns under eccentric loading, Journal of Constructional Steel Research 2011; 67 (4) : 623-633.

Thus, Figure 6 shows the strength index (SI) in terms of $f_{\text {ck }}, \theta$ and $\lambda$ for the experiments with a diameter $\mathrm{D}=100 \mathrm{~mm}$. Figure 6.a and Figure 6.e display that if $\mathrm{f}_{\mathrm{ck}}$ increases, the relative slenderness $(\lambda)$ increases and the SI decreases.

If the length is increased the SI is reduced but the reduction is higher when the eccentricity is increased.

It seems that the reduction of SI is higher for normal strength concrete than for high strength concrete. This is because the numerator of equation 4 (Nmax) increases quickly for NSC and slowly for HSC in comparison with the denominator $\left(\mathrm{A}_{\mathrm{c}} \mathrm{f}_{\mathrm{ck}}+\mathrm{A}_{\mathrm{y}} \cdot \mathrm{f}_{\mathrm{yk}}\right)$ which increases proportionally.

Figure 6.c shows similar tendencies to the previous figures: when the confinement index increases, the strength index also increases.

Nevertheless, what it is noticeable is that the strength index (SI) does not seem to be greatly affected by the thickness of the section, since similar results are obtained between the 100.3 series and 100.5 series, although for lower values of $\mathrm{D} / \mathrm{t}$ the $\mathrm{SI}$ is slightly higher, Figure 6.b.

It is interesting to note the influence of the eccentricity in the cases of tests with $\mathrm{L}=3$ meters (taking into account all the diameters and thicknesses), Figure 7. The theoretical reduction factor $\chi$ for concentrically-loaded members from Eurocode 4 was also included. It can be shown that the shapes of the curves are similar to the theoretical one. The reduction of the maximum load has a greater influence for $\mathrm{e}=20 \mathrm{~mm}$ than for $\mathrm{e}=$ $50 \mathrm{~mm}$. This is because the second order effects and imperfections are more important for smaller eccentricities than for larger ones. The curves seem to tend to an asymptote, but this cannot be definitively stated without more data.

4.3.- Ductility Index (DI). 
Portolés J1, Romero ML*, Bonet JL and Filippou FC, Experimental study of high strength concrete-filled circular tubular columns under eccentric loading, Journal of Constructional Steel Research 2011; 67 (4) : 623-633.

The ductility of composite columns is one of the most interesting advantages in the comparison of reinforced concrete structures, most especially referring to HSC.

The ductility index can be defined as the ratio between the displacement corresponding to $85 \%$ of the maximum load (in the descending branch) and the displacement from the maximum load:

$$
\mathrm{DI}=\frac{\mathrm{d}\left(0.85 \mathrm{~N}_{\max }\right)}{\mathrm{d}\left(\mathrm{N}_{\max }\right)}
$$

Table 3 presents the DI for all the experiments. It is also interesting to look at the graphic representation of the results from the force-displacement curves, Figure 2.

It is apparent that the ductility is reduced when increasing the strength of the concrete but ductile behavior is still achieved. In general, the eccentricity and the ductility increase at the same time. This was also observed for short columns by O'Shea and Bridge [8] .

It is worth mentioning that a higher DI is obtained for the experiments with lower $\mathrm{D} / \mathrm{t}$ ratio, which means that a thicker tube gives a higher DI, which may be associated with the fact that confinement appears in post-peak behavior.

For the strength cases the residual capacity is lower when the slenderness is lower.

All these statements lead to the conclusion that the use of slender high strength composite columns is appealing because although they resist less axial force than the members with a lower L/D ratio, they obtain a good ductile behavior.

\section{COMPARISON WITH EUROCODE 4}

The design of normal strength concrete-filled tubular columns has been well-known in Europe since the appearance of the first CIDECT [22] monograph decades ago, which 
Portolés Jl, Romero ML*, Bonet JL and Filippou FC, Experimental study of high strength concrete-filled circular tubular columns under eccentric loading, Journal of Constructional Steel Research 2011; 67 (4) : 623-633.

simplified its applicability for practical engineers. Later research works gave rise to the monograph $\mathrm{n}^{\circ} 5$, CIDECT [23]. All these documents were the basis of the first version of Eurocode 4 [1] which pays special attention to concrete-filled columns. It limits the cylinder strength of concrete to $50 \mathrm{MPa}$.

The experiments in this study aim to clarify whether the Eurocode 4 is still applicable to $100 \mathrm{Mpa}$. In actual fact, since these tests have values of $\lambda \geq 0.5$ or $\mathrm{e} \geq 0.1$, the increment in the resistance of the cross-section due to the confinement effect is ignored. In addition the partial safety factor for steel and concrete are fixed to 1 , and the empty tubes are not included in the method because these have to be calculated using Eurocode 3.

Table 1 includes the values of the axial load calculated with EC4. The accuracy ratio is defined as the ratio between the maximum experimental load and the design load according to EC4.

$$
\xi=\frac{\mathrm{N}_{\text {max,exp }}}{\mathrm{N}_{\text {max,EC4 }}}
$$

As can be shown the mean value is 1.02 and the standard deviation is 0.07 which demonstrates how accurate the code is, as confirmed by other authors [19],[21] for other types of columns. However $17 \%$ of the test gave an accuracy ratio which was very close but still under 1 .

These values are also presented in Figure 8, where all the calculated values are less than $15 \%$, and almost all tests fall within $10 \%$ of difference with the experiments. It is noted that as much higher $\mathrm{N}_{\max , \exp }$ is the more the ratio increases, the calculated load diverges from the experimental one but on the safe side.

The trend of the error $\xi$ can be drawn in terms of the strength of concrete $\left(f_{\mathrm{ck}}\right)$, the confinement ratio $(\theta)$ and the relative slenderness $(\lambda)$, Figure 9. 
Portolés J1, Romero ML*, Bonet JL and Filippou FC, Experimental study of high strength concrete-filled circular tubular columns under eccentric loading, Journal of Constructional Steel Research 2011; 67 (4) : 623-633.

From these results, it can be stated that almost all the cases of high strength concrete, except 4 , are on the safe side ( $\xi>1)$. No influence is observed from $\mathrm{e} / \mathrm{D}$ or $\mathrm{D} / \mathrm{t}$, but when the "f $\mathrm{f}_{\mathrm{ck}}$ " increases so does $\xi$.

A common factor for most of the cases on the unsafe side is a value of $\theta>1$ with lower slenderness. This indicates that the Eurocode 4 is less accurate in predicting in the cases where the section or the member is coarser due to the prediction of $\mathrm{N}_{\mathrm{pl}, \mathrm{Rd}}$ or the stiffness of the element (E.I).

Accordingly, the authors consider that it is necessary to provide more data to achieve reliable results. To do so a numerical model for the accurate prediction of high-strength concrete composite columns is needed.

\section{CONCLUSIONS}

In this paper 37 experimental tests of concrete-filled tubular columns are presented.

The experiments focus on cases with high strength concrete, slender columns and high eccentricity.

It has been shown that for cases of more slender columns with higher eccentricity increasing the strength of the concrete too much is not of great use because no increment in the maximum load is obtained when comparing 70 to $90 \mathrm{MPa}$, but the use of HSC composite columns is still of interest for the limited cases analyzed since they obtain a better ductile behavior.

It is worthwhile to remark that this ductility improvement may be useful only in special cases (e.g. resistance against blast effects, robustness for earthquake response, etc.). 
Portolés J1, Romero ML*, Bonet JL and Filippou FC, Experimental study of high strength concrete-filled circular tubular columns under eccentric loading, Journal of Constructional Steel Research 2011; 67 (4) : 623-633.

In fact, the tendency of the concrete contribution ratio is a combination of the relative slenderness and the confinement index, but more experimental cases or a numerical parametric study are needed to reach a reliable conclusion.

If the parameter strength index (SI) is studied, it seems that the reduction of SI is higher for normal strength concrete than for high strength concrete, being not greatly affected by the thickness of the section. However, the reduction of the maximum load has a greater influence for $\mathrm{e}=20 \mathrm{~mm}$ than for $\mathrm{e}=50 \mathrm{~mm}$. This is because the second order effects and imperfections are more important for smaller eccentricities than for larger ones.

The experimental ultimate load of each test was compared with the design loads from Eurocode 4. The mean value is 1.02 and the standard deviation is 0.07 which demonstrates how accurate the code is. However, $17 \%$ of the test gave an accuracy ratio which was very close but still under 1 . A common factor for most of the cases on the unsafe side is a value of $\theta>1$ with lower slenderness. This indicates that the Eurocode 4 is less accurate in predicting in the cases where the section or the member is coarser due to the prediction of $\mathrm{N}_{\mathrm{pl}, \mathrm{Rd}}$ or the stiffness of the element (E.I).

\section{ACKNOWLEDGEMENTS}

The authors wish to express their sincere gratitude to the Spanish Ministry of Education for help provided through project BIA2005_255 and BIA 2009_09411, to the European Community for FEDER funds, and to the Fundació Caixa Castelló- Bancaixa.

\section{REFERENCES}

[1] European Committee of Standardization. EN 1994-1-1:2004 Eurocode 4: Design of composite steel and concrete structures Part 1-1: General rules and rules for buildings. 2004 . 
Portolés Jl, Romero ML*, Bonet JL and Filippou FC, Experimental study of high strength concrete-filled circular tubular columns under eccentric loading, Journal of Constructional Steel Research 2011; 67 (4) : 623-633.

[2] Shams M, Saadeghvaziri MA, State of the art of concrete-filled steel tubular columns , ACI Structural Journal 1997; 94 (5). 558-571.

[3] Shanmugam NE, Lakshmi B, State of the art report on steel-concrete composite columns, Journal of constructional steel research 2001, 57 (10): 1041-1080.

[4] Gourley, B. C., Tort, C., Denavit, M. D., Schiller, P. H., and Hajjar, J. F. A Synopsis of Studies of the Monotonic and Cyclic Behavior of Concrete-Filled Steel Tube Beam-Columns, Report No. UILU-ENG-2008-1802, Newmark Structural Laboratory Report Series (ISSN 1940-9826), Department of Civil and Environmental Engineering, University of Illinois at Urbana-Champaign, Urbana, Illinois, April. 2008

[5] Johansson M., Gylltoft K. Structural behaviour of slender circular steel- concrete composite columns under various means of load application. Steel and Composite Structures 2001; 1(4):393-410.

[6] Johansson, M. Composite Action and Confinement Effects in Tubular SteelConcrete Columns. Department of Structural Engineering, Chalmers University of Technology, Doctoral Thesis, Publication 02:8, Göteborg, Sweden, November 2002, 173 pp.

[7] Zeghiche J, Chaoui K. An experimental behaviour of concrete-filled steel tubular columns. J Construct Steel Res 2005; 61(1): 53-66.

[8] O'Shea MD, Bridge RQ. Design of circular thin-walled concrete filled steel tubes. Journal of structural engineering-ASCE Eng 2000; 126(11):1295-1303.

[9] Han L.H., Tests on concrete filled steel tubular columns with high slenderness ratio, Advances in Structural Engineering 2000; 3(4): 337-344.

[10] Shakir-Khalil H., Mouli M. Further tests on concrete-filled rectangular hollowsection columns, The Structural Engineer, 1990, 68(20):405-413.

[11] Sakino K, Nakahara H, Morino S, Nishiyama A, Behavior of centrally loaded concrete-filled steel-tube short columns, Journal of structural engineering-ASCE 2004; 130(2): 180-188.

[12] Fujimoto T, Mukai A, Nishiyama I, Sakino K, Behavior of eccentrically loaded concrete-filled steel tubular columns, Journal of structural engineering-ASCE 2004, 130(2): 203-212.

[13] Grauers M. Composite columns of hollow sections filled with high strength concrete. Research report. Chalmers University of Technology, Goteborg, 1993.

[14] Bergmann, R. Load introduction in composite columns filled with high strength concrete, Proceedings of the 6th Int Symposium on Tubular Structures, Monash University, Melbourne, Australia, 1994.

[15] Rangan B. and Joyce M. Strength of eccentrically loaded slender steel tubular columns filled with high-strength concrete, ACI Struct J 1992; 89 (6): 676-681.

[16] Kilpatrick A.E. and Rangan B.V. Tests on high-strength concrete-filled steel tubular columns. ACI Struct J 1999; 96 (2): 268-275.

[17] Liu DL, Gho WM. and Yuan H. Ultimate capacity of high-strength rectangular concrete-filled steel hollow section stub columns. J Construct Steel Res 2003; 59 (12): 1499-1515.

[18] Varma AH, Ricles JM, Sause R, Lu L-W. Experimental behaviour of high strength square concrete-filled steel tube beam-columns. J Struct Eng ASCE 2002; 128(3):309-327.

[19] Yu Q., Tao Z., Wu Y.X. Experimental behaviour of high performance concretefilled steel tubular columns. Thin-Walled Struct. 2008 (46) 362-370. 
Portolés J1, Romero ML*, Bonet JL and Filippou FC, Experimental study of high strength concrete-filled circular tubular columns under eccentric loading, Journal of Constructional Steel Research 2011; 67 (4) : 623-633.

[20] Giakomelis G. Lam D. Axial Capacity of circular concrete-filled tube columns. Journal of Constructional Steel Research 2004; 60:1049-1068.

[21] Goode, CD. Composite columns-1819 tests on concrete filled tube columns compared with Eurocode 4, The Structural Engineer 2008, 86(16): 33-38.

[22] CIDECT Monograph num. 1: Concrete filled hollow section steel columns design manual, British edition. 1970.

[23] CIDECT Monograph $n^{\circ}$ 5: Calcules Poteaux en Proliles Creux remplis de Béton. 1979. 
Portolés Jl, Romero ML*, Bonet JL and Filippou FC, Experimental study of high strength concrete-filled circular tubular columns under eccentric loading, Journal of Constructional Steel Research 2011; 67 (4) : 623-633.
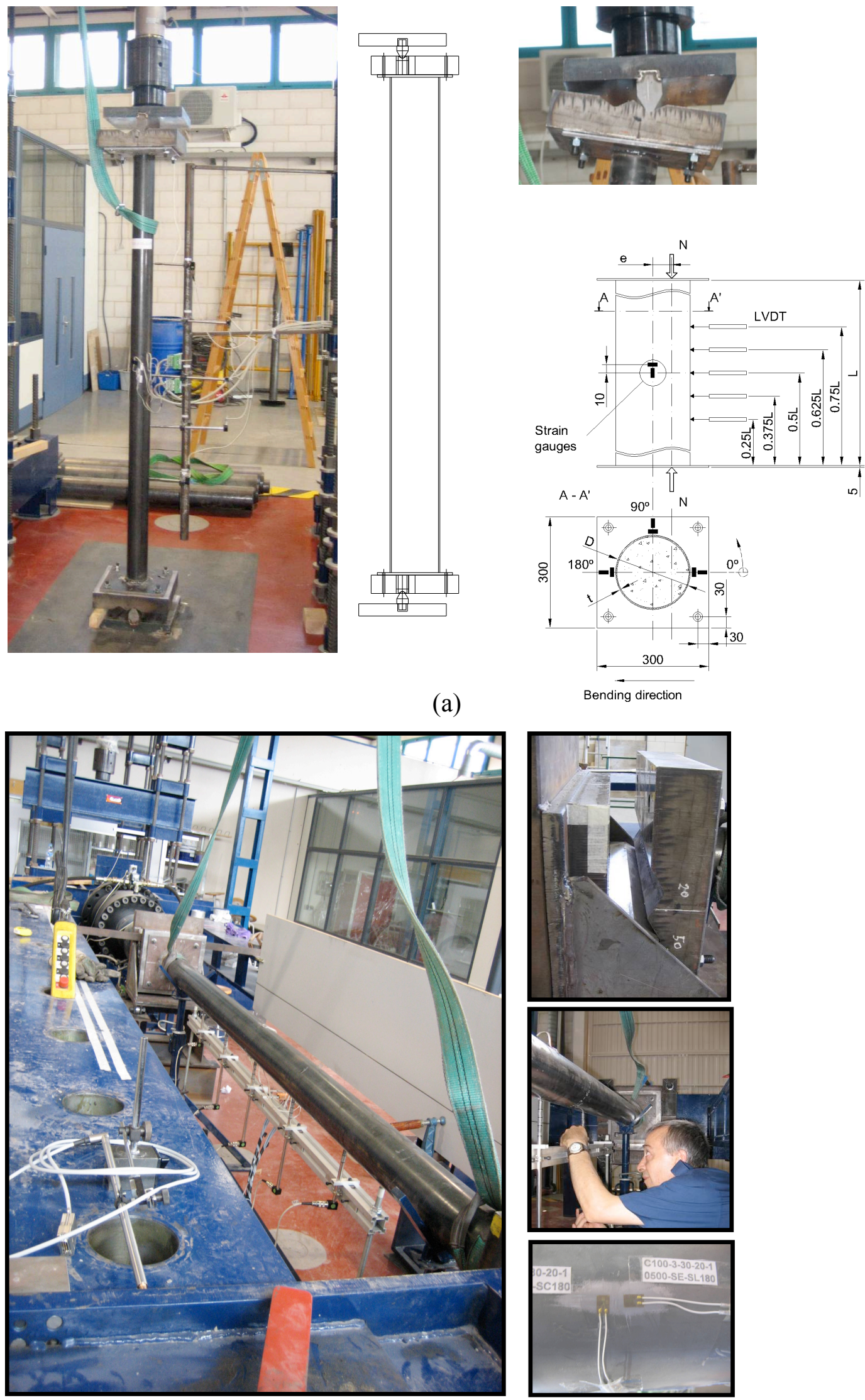

(b) 
Portolés Jl, Romero ML*, Bonet JL and Filippou FC, Experimental study of high strength concrete-filled circular tubular columns under eccentric loading, Journal of Constructional Steel Research 2011; 67 (4) : 623-633.

Figure 1. General view of the sensor location (a) Vertical Tests (b) Horizontal arrangement

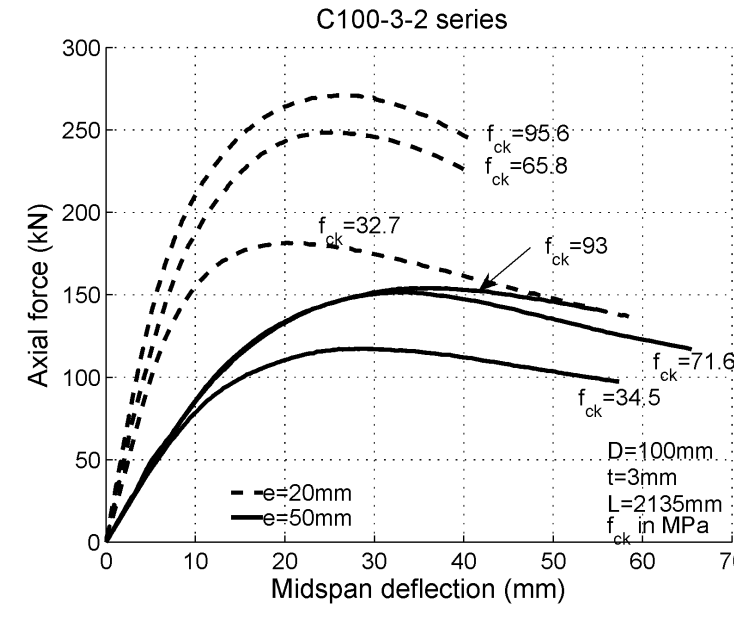

a)

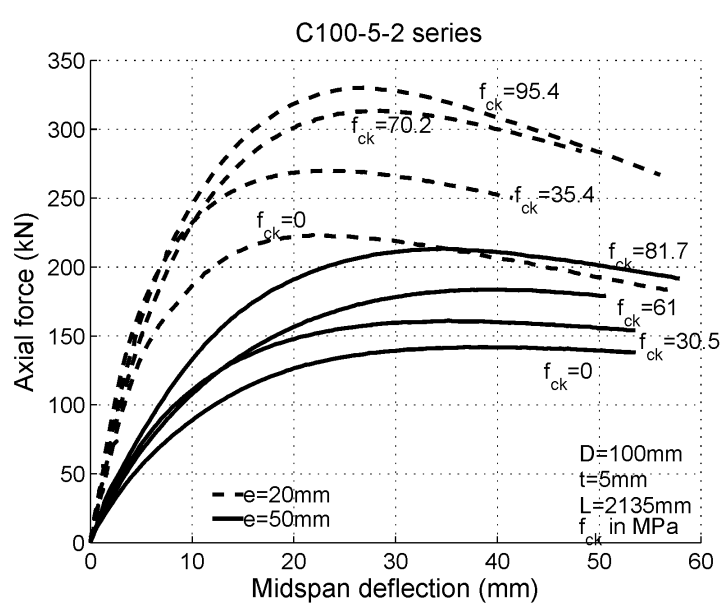

c)

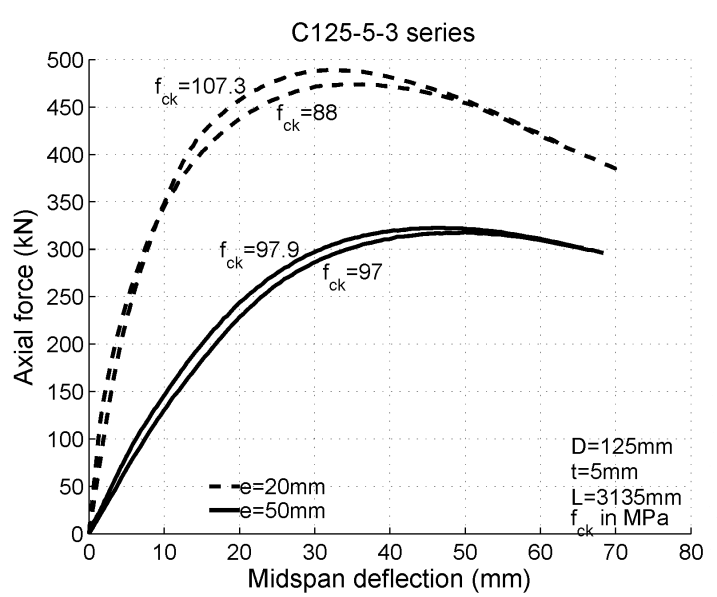

e)

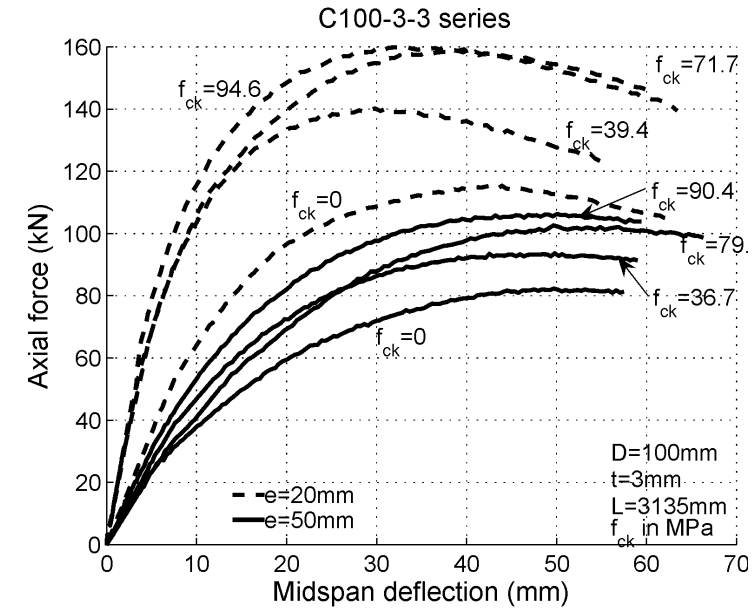

b)

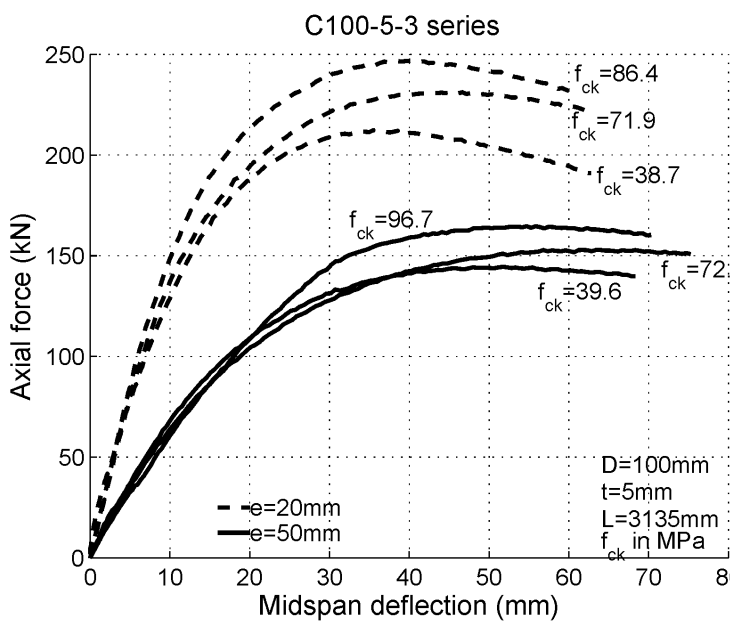

d)

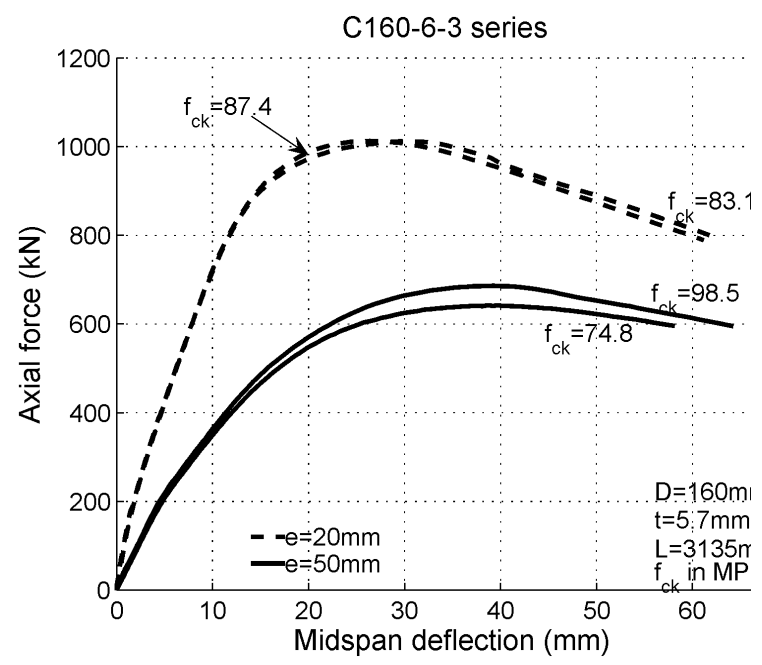

f)

Figure 2. Axial load versus mid-span displacement series 
Portolés Jl, Romero ML*, Bonet JL and Filippou FC, Experimental study of high strength concrete-filled circular tubular columns under eccentric loading, Journal of Constructional Steel Research 2011; 67 (4) : 623-633.

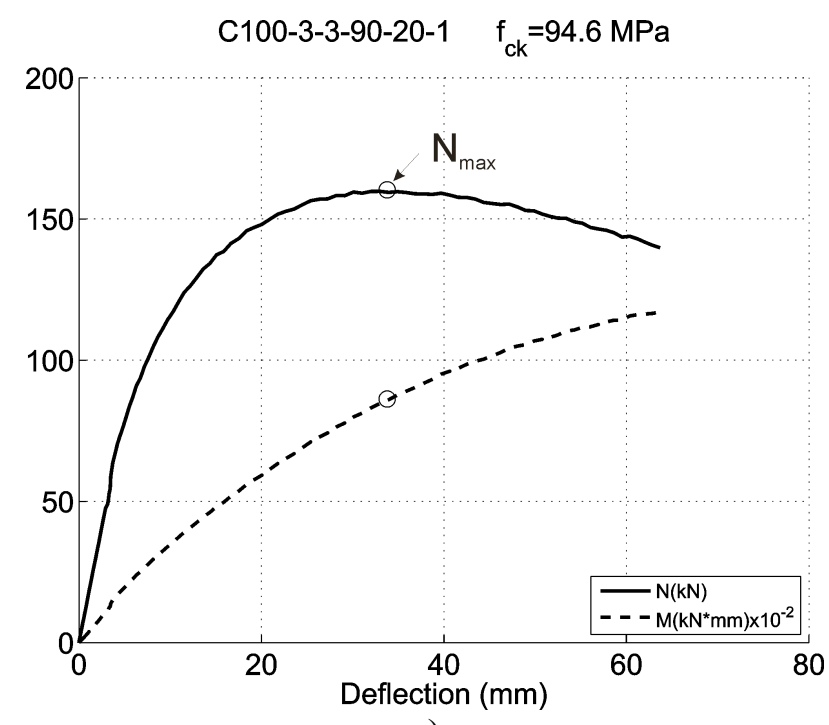

a)

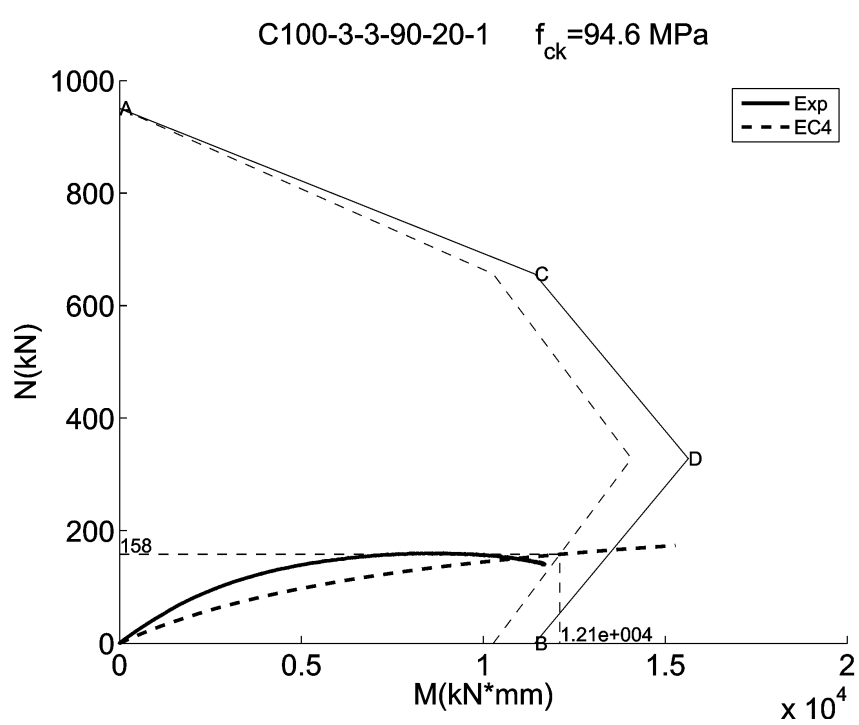

b)

Figure 3. Failure Mode. a) Axial load and bending moment versus displacement.

b) Interaction diagram, 
Portolés Jl, Romero ML*, Bonet JL and Filippou FC, Experimental study of high strength concrete-filled circular tubular columns under eccentric loading, Journal of Constructional Steel Research 2011; 67 (4) : 623-633.

\section{C100-5-2 strain series}

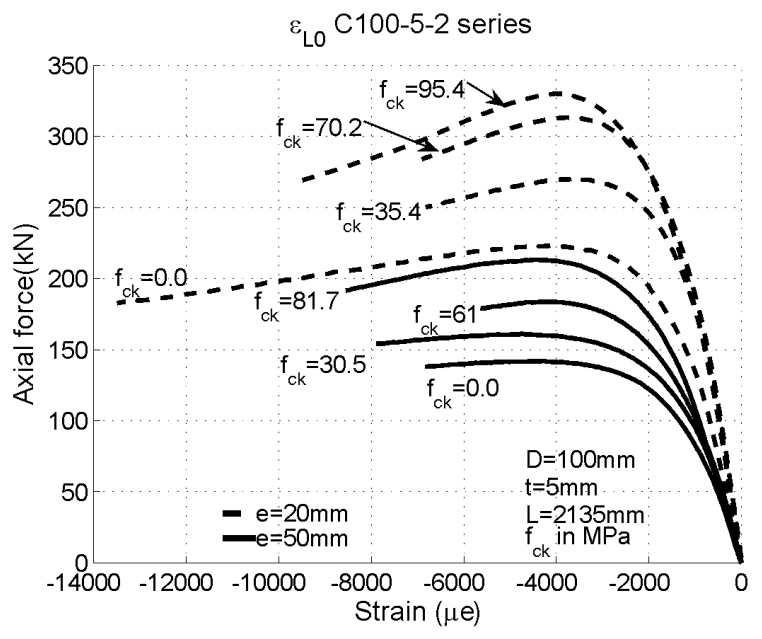

a)

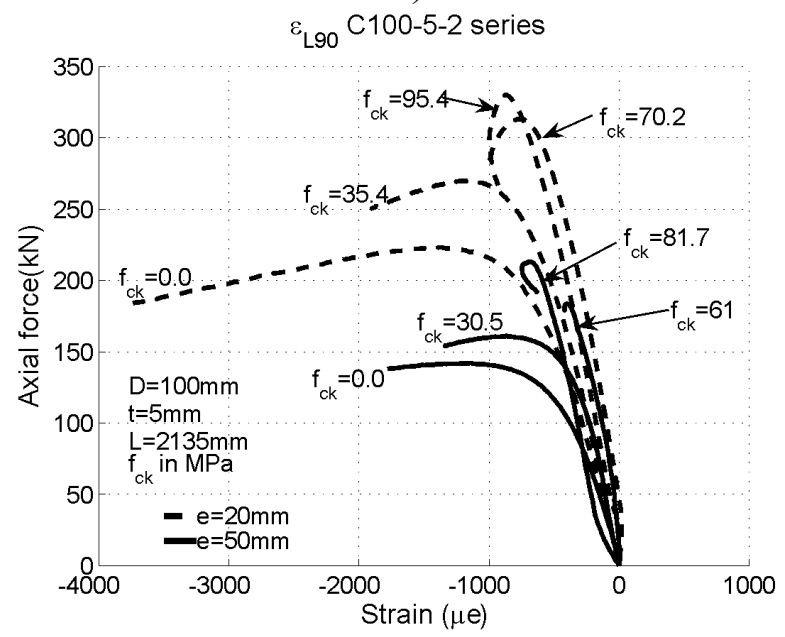

c)

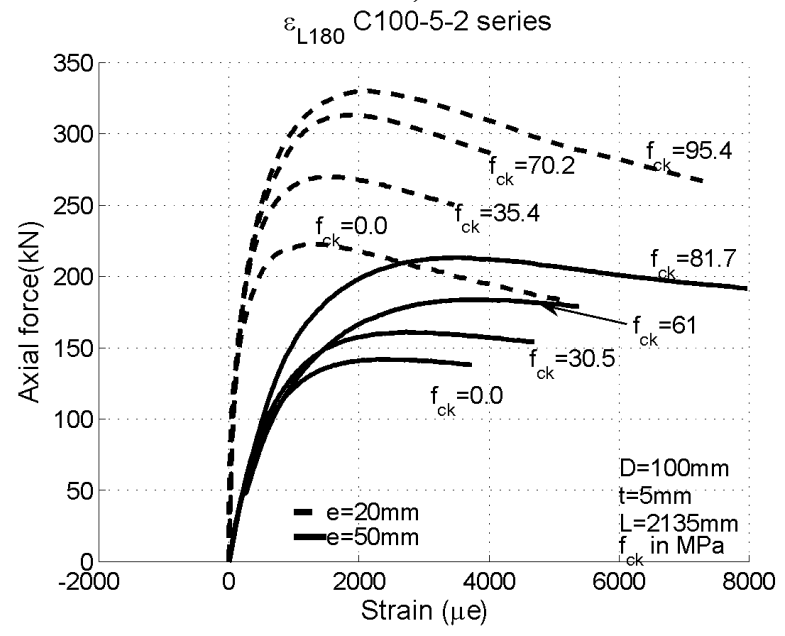

e)

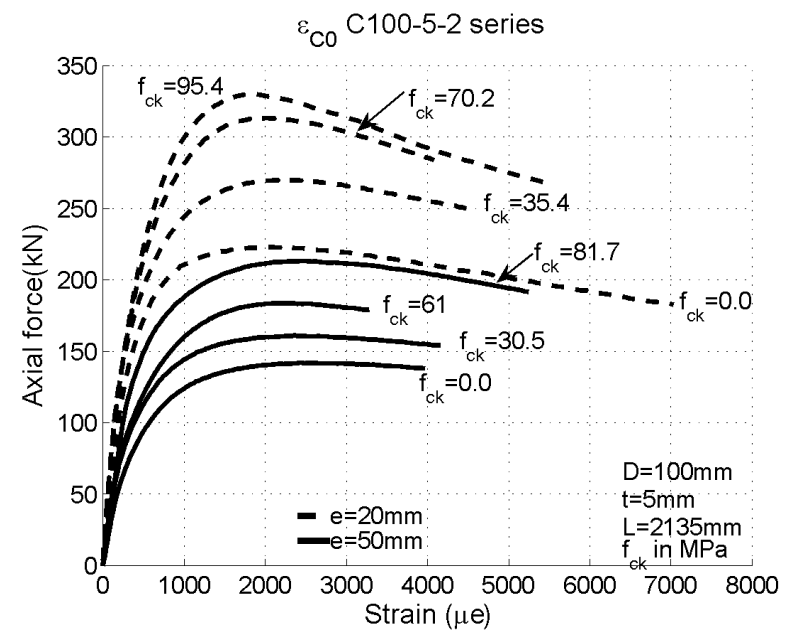

b)

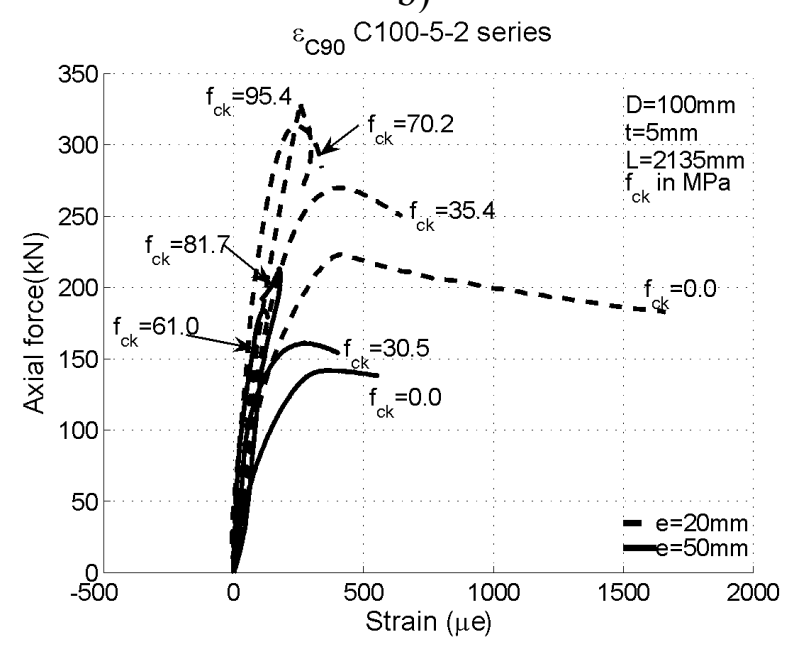

d)

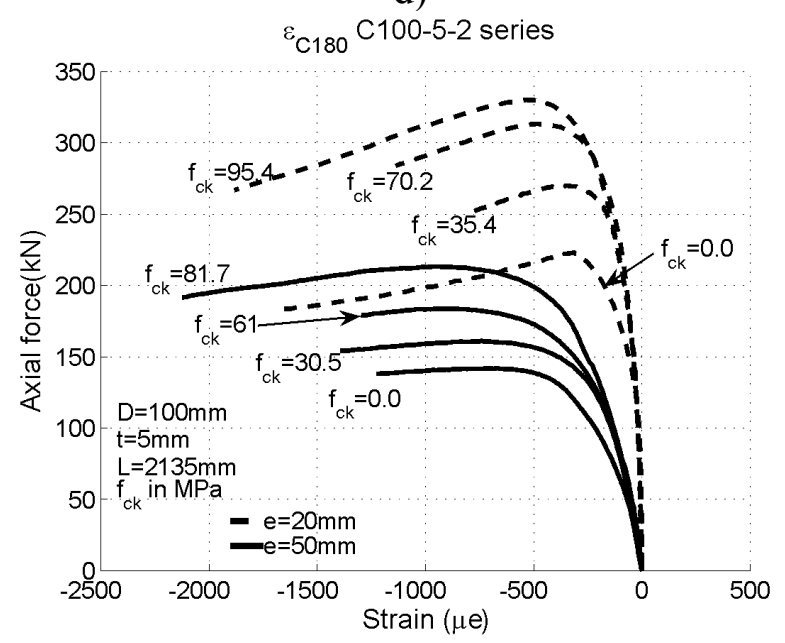

f)

Figure 4. Axial force versus longitudinal, $\varepsilon_{\mathrm{L}}$, and circumferential strains, $\varepsilon_{\mathrm{C}}$ at $0^{\circ}, 90^{\circ}$ and $180^{\circ}$ (see Figure 1) 
Portolés Jl, Romero ML*, Bonet JL and Filippou FC, Experimental study of high strength concrete-filled circular tubular columns under eccentric loading, Journal of Constructional Steel Research 2011; 67 (4) : 623-633.

\section{Concrete confinement ratio (CCR)}

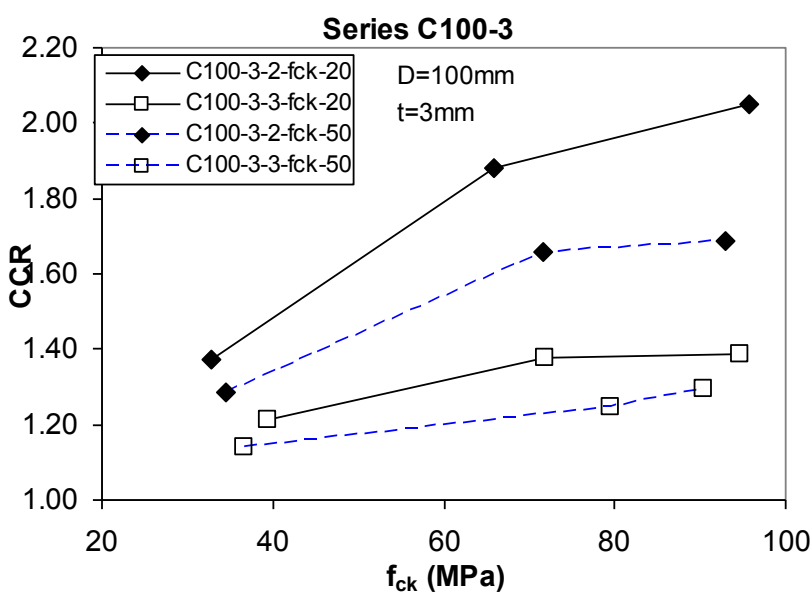

a)

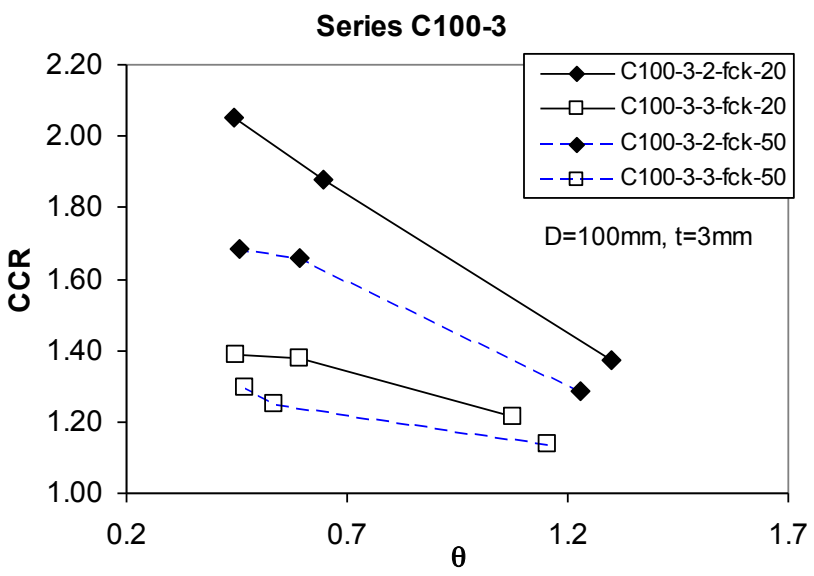

c)

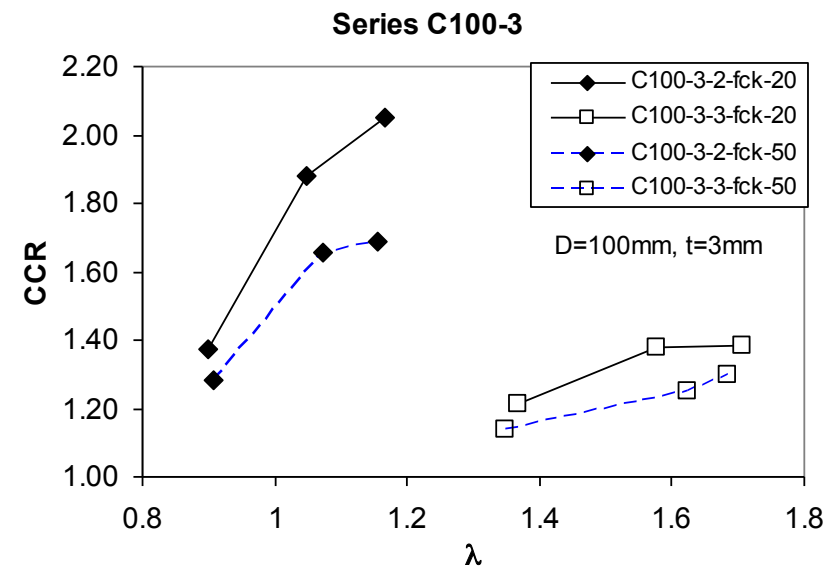

e)

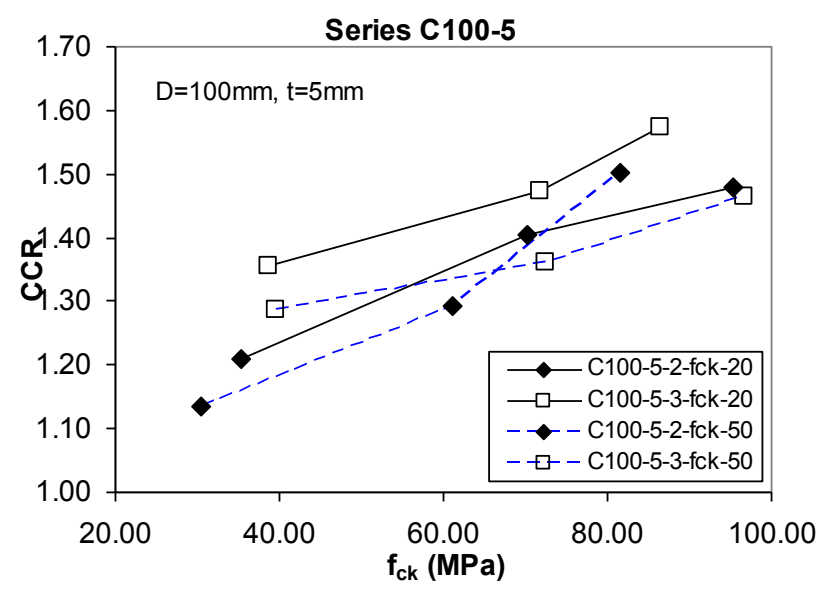

b)

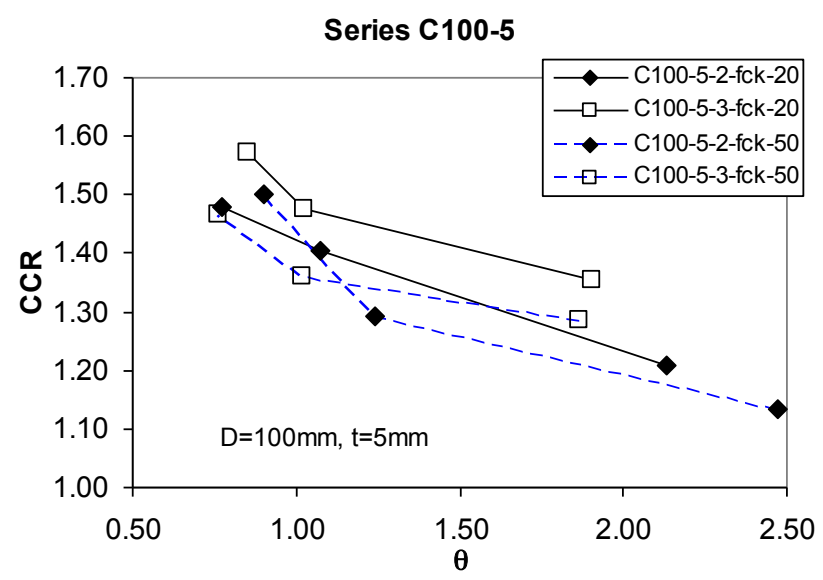

d)

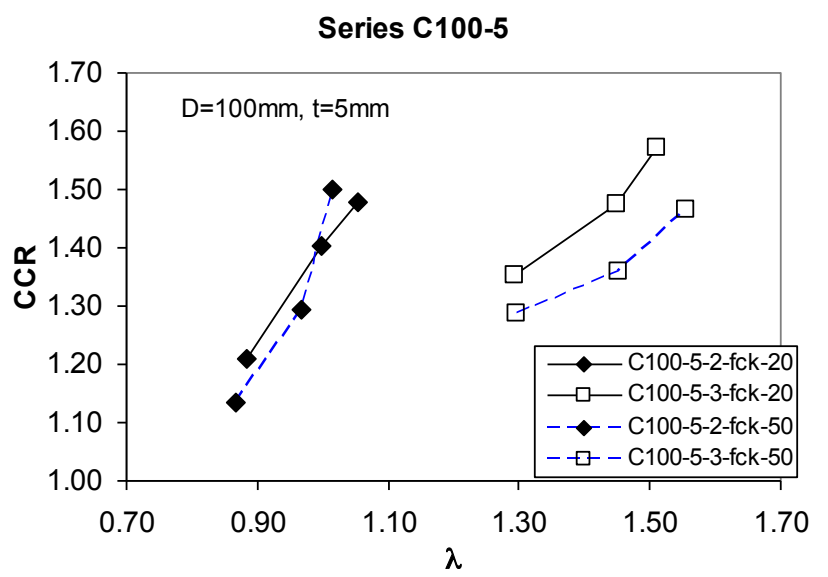

Figure 5. Concrete contribution ratio for the test with $\mathrm{D}=100 \mathrm{~mm}$. 
Portolés Jl, Romero ML*, Bonet JL and Filippou FC, Experimental study of high strength concrete-filled circular tubular columns under eccentric loading, Journal of Constructional Steel Research 2011; 67 (4) : 623-633.

\section{Strength Index (SI)}

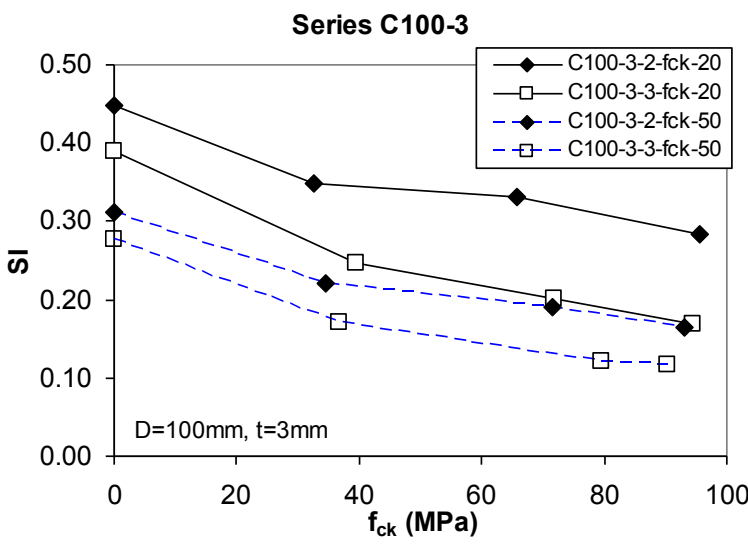

a)

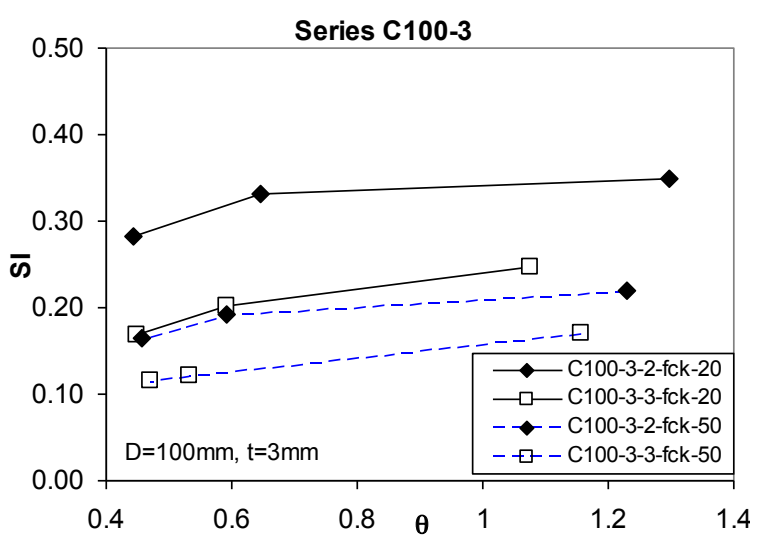

c)

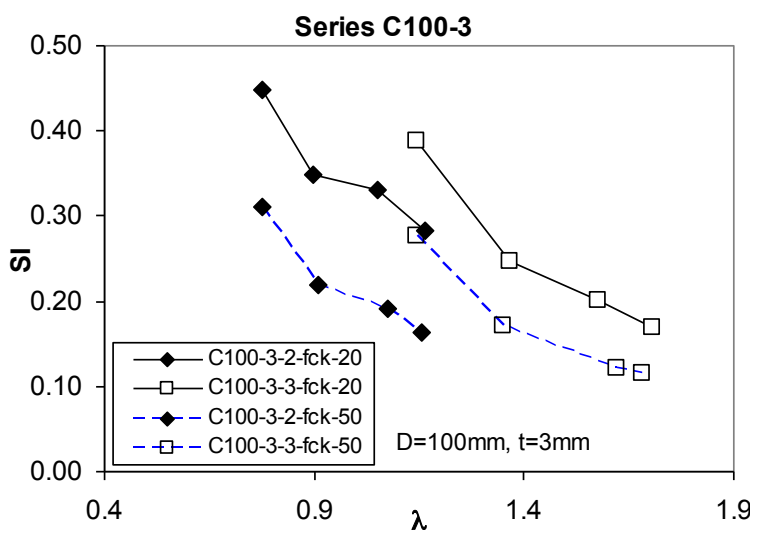

e)

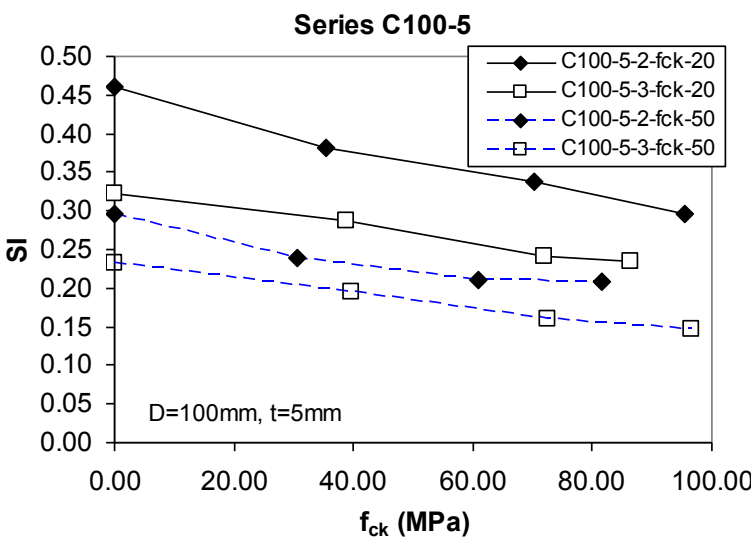

b)

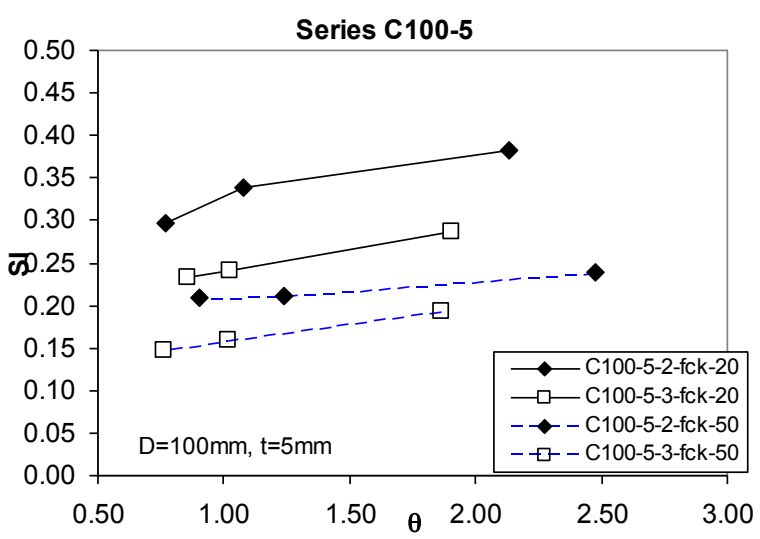

d)

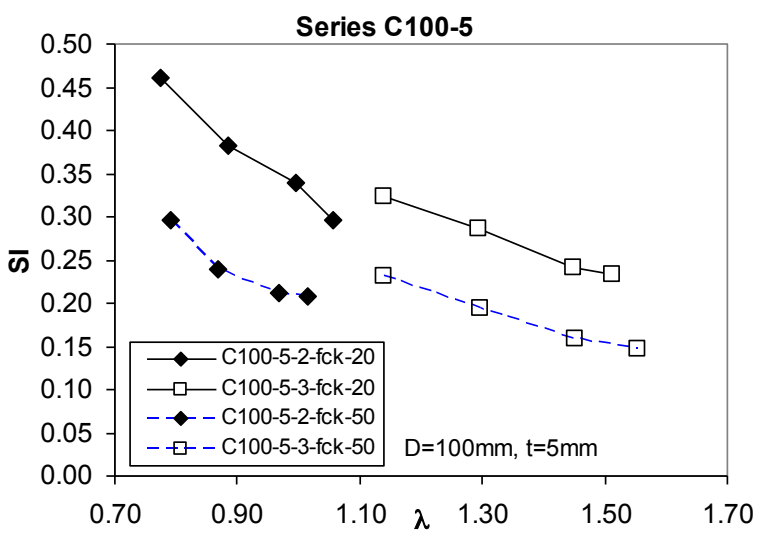

f)

Figure 6. Strength Index (SI) for the test with $\mathrm{D}=100 \mathrm{~mm}$. 
Portolés J1, Romero ML*, Bonet JL and Filippou FC, Experimental study of high strength concrete-filled circular tubular columns under eccentric loading, Journal of Constructional Steel Research 2011; 67 (4) : 623-633.

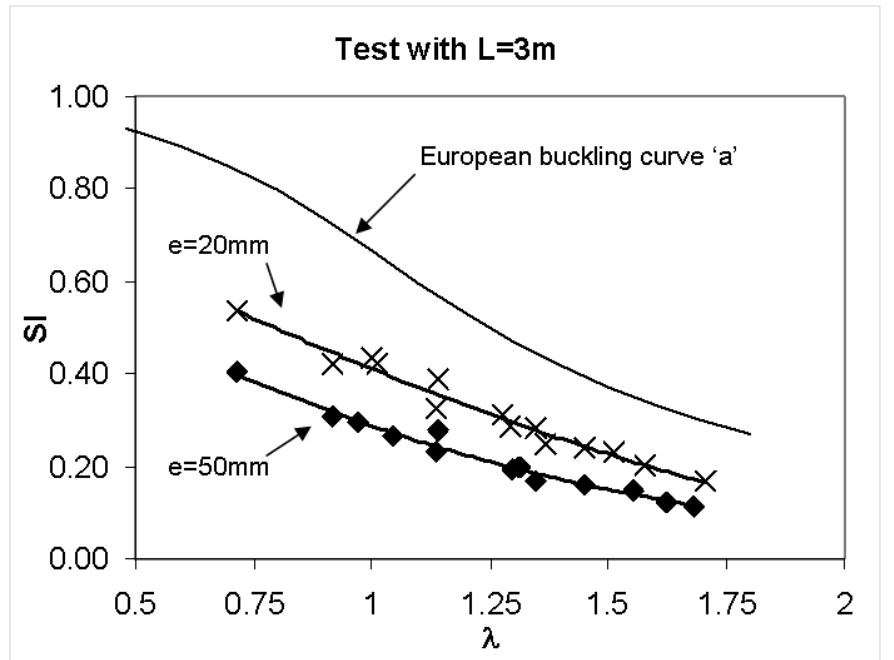

Figure 7. Strength Index (SI): dependence of the eccentricity for tests with $\mathrm{L}=3 \mathrm{~m}$. 
Portolés J1, Romero ML*, Bonet JL and Filippou FC, Experimental study of high strength concrete-filled circular tubular columns under eccentric loading, Journal of Constructional Steel Research 2011; 67 (4) : 623-633.

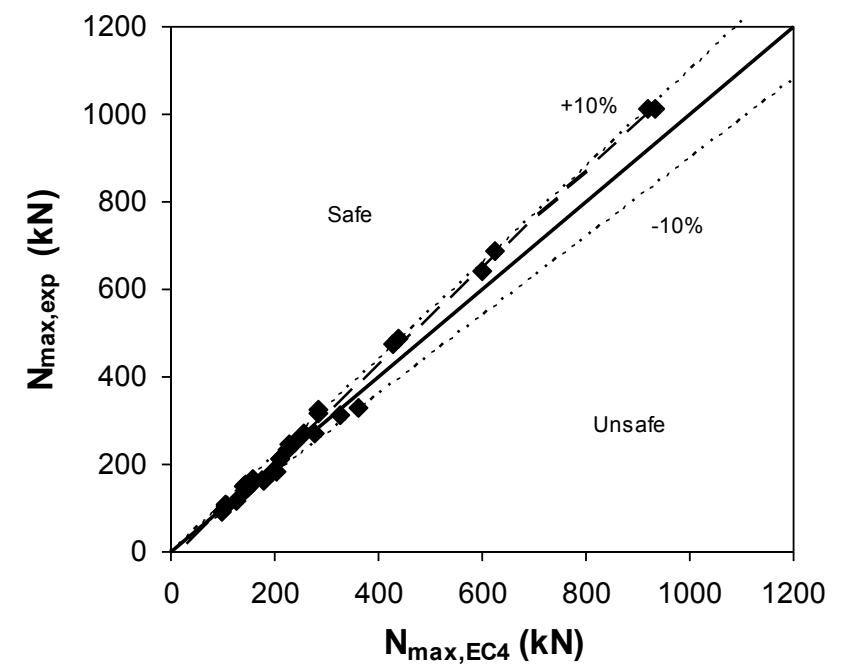

Figure 8. Accuracy degree between experimental ultimate load and Eurocode 4 provisions 
Portolés Jl, Romero ML*, Bonet JL and Filippou FC, Experimental study of high strength concrete-filled circular tubular columns under eccentric loading, Journal of Constructional Steel Research 2011; 67 (4) : 623-633.

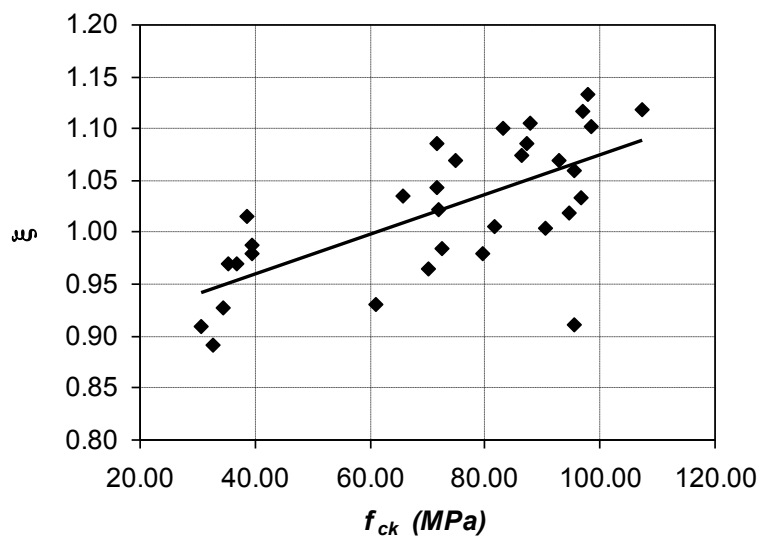

a)

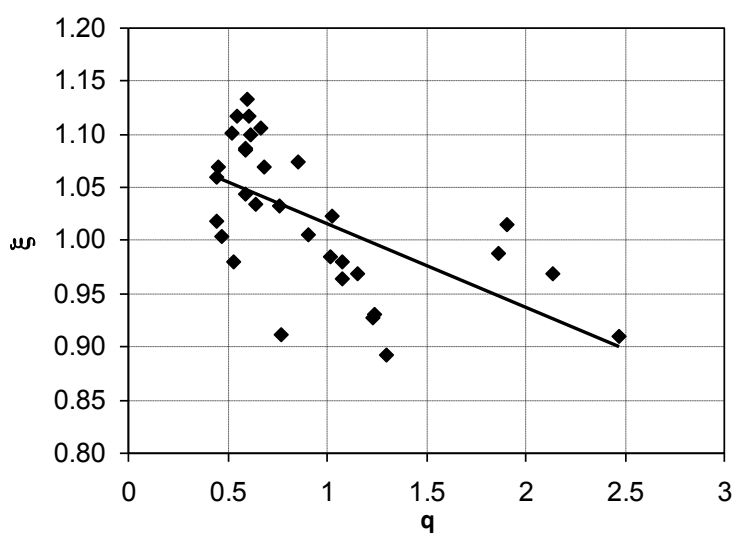

b)

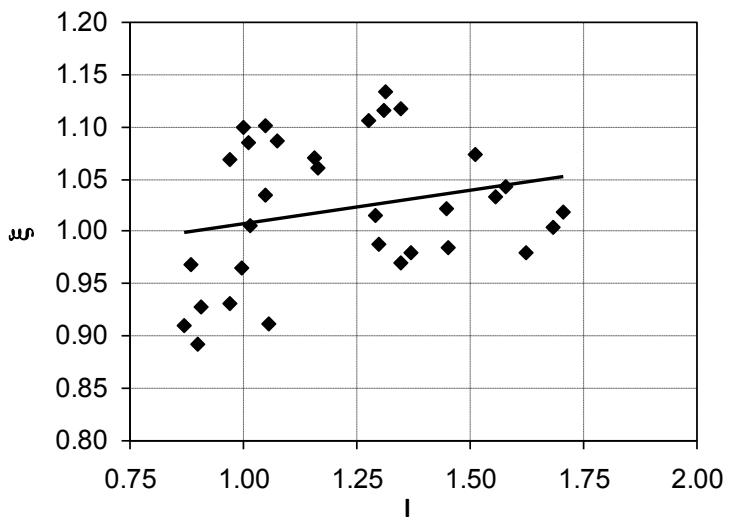

c)

Figure 9. Error of Eurocode 4. 
Portolés J1, Romero ML*, Bonet JL and Filippou FC, Experimental study of high strength concrete-filled circular tubular columns under eccentric loading, Journal of Constructional Steel Research 2011; 67 (4) : 623-633.

Table 1. Test properties and results

\begin{tabular}{|c|c|c|c|c|c|c|c|c|c|c|}
\hline Id & Name & $\underset{\mathbf{m m}}{\mathrm{D}}$ & $\underset{\mathbf{m m}}{\mathbf{t}}$ & $\underset{\mathbf{m m}}{\mathbf{L}}$ & $\underset{\mathbf{m m}}{\mathrm{e}}$ & $\begin{array}{c}\mathbf{f}_{\mathbf{y k}} \\
(\mathbf{M P a})\end{array}$ & $\begin{array}{c}\mathbf{f}_{\mathrm{ck}} \\
(\mathbf{M P a})\end{array}$ & $\begin{array}{l}\mathbf{N}_{\mathrm{u}, \text { exp }} \\
(\mathbf{k N})\end{array}$ & $\begin{array}{c}\mathbf{N}_{\mathrm{u}, \mathrm{EC} 4} \\
(\mathbf{k N})\end{array}$ & $\xi$ \\
\hline $\mathrm{C} 1$ & C100-3-2-30-20-1 & 100 & 3 & 2135 & 20 & 322 & 32.70 & 181.56 & 203.49 & 0.89 \\
\hline $\mathrm{C} 2$ & C100-3-2-30-50-1 & 100 & 3 & 2135 & 50 & 322 & 34.50 & 117.49 & 126.60 & 0.93 \\
\hline $\mathrm{C} 3$ & C100-3-2-70-20-1 & 100 & 3 & 2135 & 20 & 322 & 65.79 & 248.58 & 240.23 & 1.03 \\
\hline $\mathrm{C} 4$ & C100-3-2-70-50-1 & 100 & 3 & 2135 & 50 & 322 & 71.64 & 151.59 & 139.58 & 1.09 \\
\hline $\mathrm{C} 5$ & C100-3-2-90-20-1 & 100 & 3 & 2135 & 20 & 322 & 95.63 & 271.04 & 255.69 & 1.06 \\
\hline $\mathrm{C} 6$ & C100-3-2-90-50-1 & 100 & 3 & 2135 & 50 & 322 & 93.01 & 154.24 & 144.19 & 1.07 \\
\hline $\mathrm{C} 7$ & C100-3-3-00-20-1 & 100 & 3 & 3135 & 20 & 325 & 0 & 115.66 & & $* *$ \\
\hline $\mathrm{C} 8$ & C100-3-3-00-50-1 & 100 & 3 & 3135 & 50 & 325 & 0 & 82.321 & & $* *$ \\
\hline C9 & C100-3-3-30-20-1 & 100 & 3 & 3135 & 20 & 322 & 39.43 & 140.32 & 143.19 & 0.98 \\
\hline $\mathrm{C} 10$ & C100-3-3-30-50-1 & 100 & 3 & 3135 & 50 & 322 & 36.68 & 93.75 & 96.72 & 0.97 \\
\hline $\mathrm{C} 11$ & C100-3-3-70-20-1 & 100 & 3 & 3135 & 20 & 322 & 71.74 & 159.55 & 152.90 & 1.04 \\
\hline $\mathrm{C} 12$ & C100-3-3-70-50-1 & 100 & 3 & 3135 & 50 & 322 & 79.55 & 102.75 & 104.86 & 0.98 \\
\hline $\mathrm{C} 13$ & C100-3-3-90-20-1 & 100 & 3 & 3135 & 20 & 322 & 94.56 & 160.33 & 157.41 & 1.02 \\
\hline C14 & C100-3-3-90-50-1 & 100 & 3 & 3135 & 50 & 322 & 90.40 & 106.8 & 106.31 & 1.00 \\
\hline $\mathrm{C} 15$ & C100-5-2-00-20-1 & 101.6 & 5 & 2135 & 20 & 320 & 0 & 223.37 & & $* *$ \\
\hline $\mathrm{C} 16$ & C100-5-2-00-20-2* & 101.6 & 5 & 2135 & 20 & 320 & 0 & 226.61 & & $* *$ \\
\hline $\mathrm{C} 17$ & C100-5-2-00-50-1 & 100 & 5 & 2135 & 50 & 322 & 0 & 142.19 & & $* *$ \\
\hline $\mathrm{C} 18$ & C100-5-2-30-20-1 & 100 & 5 & 2135 & 20 & 322 & 35.39 & 270.02 & 278.64 & 0.97 \\
\hline $\mathrm{C} 19$ & C100-5-2-30-50-1 & 100 & 5 & 2135 & 50 & 322 & 30.54 & 161.26 & 177.31 & 0.91 \\
\hline $\mathrm{C} 20$ & C100-5-2-70-20-1 & 100 & 5 & 2135 & 20 & 322 & 70.16 & 313.55 & 324.95 & 0.96 \\
\hline $\mathrm{C} 21$ & C100-5-2-70-50-1 & 100 & 5 & 2135 & 50 & 322 & 61.00 & 183.81 & 197.39 & 0.93 \\
\hline $\mathrm{C} 22$ & C100-5-2-90-20-1 & 101.6 & 5 & 2135 & 20 & 320 & 95.43 & 330.4 & 362.45 & 0.91 \\
\hline $\mathrm{C} 23$ & C100-5-2-90-50-1 & 101.6 & 5 & 2135 & 50 & 320 & 81.66 & 213.46 & 212.17 & 1.01 \\
\hline $\mathrm{C} 24$ & C100-5-3-30-20-1 & 101.6 & 5 & 3135 & 20 & 320 & 38.67 & 212.48 & 209.32 & 1.02 \\
\hline $\mathrm{C} 25$ & C100-5-3-30-50-1 & 101.6 & 5 & 3135 & 50 & 320 & 39.56 & 144.83 & 146.51 & 0.99 \\
\hline $\mathrm{C} 26$ & C100-5-3-70-20-1 & 101.6 & 5 & 3135 & 20 & 320 & 71.86 & 231.35 & 226.23 & 1.02 \\
\hline $\mathrm{C} 27$ & C100-5-3-70-50-1 & 101.6 & 5 & 3135 & 50 & 320 & 72.49 & 153.16 & 155.50 & 0.98 \\
\hline $\mathrm{C} 28$ & C100-5-3-90-20-1 & 101.6 & 5 & 3135 & 20 & 320 & 86.39 & 246.82 & 229.77 & 1.07 \\
\hline $\mathrm{C} 29$ & C100-5-3-90-50-1 & 101.6 & 5 & 3135 & 50 & 320 & 96.74 & 164.95 & 159.64 & 1.03 \\
\hline C30 & C125-5-3-90-20-1 & 125 & 5 & 3135 & 20 & 322 & 87.98 & 474.17 & 428.81 & 1.11 \\
\hline $\mathrm{C} 31$ & C125-5-3-90-50-1 & 125 & 5 & 3135 & 50 & 322 & 96.97 & 317.9 & 284.71 & 1.12 \\
\hline $\mathrm{C} 32$ & C125-5-3-90-20-2* & 125 & 5 & 3135 & 20 & 322 & 107.33 & 489.47 & 437.93 & 1.12 \\
\hline $\mathrm{C} 33$ & C125-5-3-90-50-2* & 125 & 5 & 3135 & 50 & 322 & 97.92 & 322.97 & 285.01 & 1.13 \\
\hline C34 & C160-6-3-90-20-1 & 160.1 & 5.7 & 3135 & 20 & 322 & 87.38 & 1012.5 & 933.15 & 1.08 \\
\hline $\mathrm{C} 35$ & C160-6-3-70-50-1 & 160.1 & 5.7 & 3135 & 50 & 322 & 74.75 & 642.16 & 600.71 & 1.07 \\
\hline $\mathrm{C} 36$ & C160-6-3-90-20-2* & 160.1 & 5.7 & 3135 & 20 & 322 & 83.08 & 1011.5 & 919.49 & 1.10 \\
\hline \multirow[t]{2}{*}{ C37 } & C160-6-3-90-50-1 & 160.1 & 5.7 & 3135 & 50 & 322 & 98.50 & 686.21 & 622.82 & 1.10 \\
\hline & & & & & & & & & Mean & 1.02 \\
\hline
\end{tabular}

* Tests C16, C32 C33 and C36 were repeated to check consistency

** Ultimate loads of the empty tests have to be obtained according to Eurocode 3 
Portolés Jl, Romero ML*, Bonet JL and Filippou FC, Experimental study of high strength concrete-filled circular tubular columns under eccentric loading, Journal of Constructional Steel Research 2011; 67 (4) : 623-633.

Table 2. Mix proportions

\begin{tabular}{lccc}
$\begin{array}{l}\text { Nominal compressive cylinder } \\
\text { strength at } 28 \text { days }\end{array}$ & 30 & 70 & 90 \\
\hline Cement $(\mathrm{kg} / \mathrm{m} 3)$ & 348 & 425 & 570 \\
Water $(\mathrm{L} / \mathrm{m} 3)$ & 220 & 180 & 180 \\
Sand $(\mathrm{kg} / \mathrm{m} 3)$ & 1065 & 918 & 705 \\
Gravel $4-12 \mathrm{~mm}(\mathrm{~kg} / \mathrm{m} 3)$ & 666 & 918 & 890 \\
Silica fume $(\mathrm{kg} / \mathrm{m} 3)$ & - & - & 50 \\
Super-plasticizer $(\%$ of kg of cement) & - & 2.5 & 2.5 \\
\hline
\end{tabular}


Portolés Jl, Romero ML*, Bonet JL and Filippou FC, Experimental study of high strength concrete-filled circular tubular columns under eccentric loading, Journal of Constructional Steel Research 2011; 67 (4) : 623-633.

Table 3. Performance Indices

\begin{tabular}{|c|c|c|c|c|c|c|c|c|c|}
\hline $\mathrm{e}=20 \mathrm{~mm}$ series: & fck & e/D & $\mathrm{D} / \mathrm{t}$ & L/D & $\lambda$ & $\theta$ & CCR & SI & DI \\
\hline \multirow[t]{4}{*}{ C100-3-2-fck-20 } & 0 & 0.20 & 33.33 & 21.35 & 0.77 & & & 0.45 & 2.74 \\
\hline & 32.70 & 0.20 & 33.33 & 21.35 & 0.90 & 1.30 & 1.37 & 0.35 & 2.24 \\
\hline & 65.79 & 0.20 & 33.33 & 21.35 & 1.05 & 0.64 & 1.88 & 0.33 & 1.86 \\
\hline & 95.63 & 0.20 & 33.33 & 21.35 & 1.17 & 0.44 & 2.05 & 0.28 & 1.75 \\
\hline \multirow[t]{4}{*}{ C100-3-3-fck-20 } & 0 & 0.20 & 33.33 & 31.35 & 1.14 & & & 0.39 & 1.68 \\
\hline & 39.43 & 0.20 & 33.33 & 31.35 & 1.37 & 1.08 & 1.21 & 0.25 & 2.02 \\
\hline & 71.74 & 0.20 & 33.33 & 31.35 & 1.58 & 0.59 & 1.38 & 0.20 & 1.84 \\
\hline & 94.56 & 0.20 & 33.33 & 31.35 & 1.71 & 0.45 & 1.39 & 0.17 & 2.00 \\
\hline \multirow[t]{4}{*}{ C100-5-2-fck-20 } & 0 & 0.20 & 20.32 & 21.01 & 0.77 & & & 0.46 & 2.40 \\
\hline & 35.39 & 0.20 & 20.00 & 21.35 & 0.88 & 2.13 & 1.21 & 0.38 & 2.40 \\
\hline & 70.16 & 0.20 & 20.00 & 21.35 & 1.00 & 1.08 & 1.40 & 0.34 & 2.08 \\
\hline & 95.43 & 0.20 & 20.32 & 21.01 & 1.05 & 0.77 & 1.48 & 0.30 & 1.88 \\
\hline \multirow[t]{4}{*}{ C100-5-3-fck-20 } & $0(*)$ & 0.20 & 20.32 & 30.86 & 1.14 & & & 0.32 & 2.31 \\
\hline & 38.67 & 0.20 & 20.32 & 30.86 & 1.29 & 1.91 & 1.35 & 0.29 & 1.98 \\
\hline & 71.86 & 0.20 & 20.32 & 30.86 & 1.45 & 1.03 & 1.47 & 0.24 & 2.22 \\
\hline & 86.39 & 0.20 & 20.32 & 30.86 & 1.51 & 0.85 & 1.57 & 0.23 & 1.99 \\
\hline \multirow[t]{3}{*}{ C125-5-3-fck-20 } & $0(*)$ & 0.16 & 25.00 & 25.08 & 0.92 & & & 0.42 & 2.33 \\
\hline & 87.98 & 0.16 & 25.00 & 25.08 & 1.28 & 0.66 & 1.86 & 0.31 & 1.87 \\
\hline & 107.33 & 0.16 & 25.00 & 25.08 & 1.35 & 0.54 & 1.92 & 0.28 & 1.87 \\
\hline \multirow[t]{3}{*}{ C160-6-3-fck-20 } & $0(*)$ & 0.12 & 28.09 & 19.58 & 0.71 & & & 0.54 & 2.98 \\
\hline & 83.08 & 0.12 & 28.09 & 19.58 & 1.00 & 0.62 & 2.12 & 0.43 & 1.83 \\
\hline & 87.38 & 0.12 & 28.09 & 19.58 & 1.01 & 0.59 & 2.12 & 0.42 & 1.96 \\
\hline $\mathrm{e}=\mathbf{5 0} \mathrm{mm}$ series & fck & e/D & $\mathrm{D} / \mathrm{t}$ & L/D & $\lambda$ & $\theta$ & CCR & SI & DI \\
\hline \multirow[t]{4}{*}{ C100-3-2-fck-50 } & $0(*)$ & 0.20 & 33.33 & 21.35 & 0.77 & & & 0.31 & 2.57 \\
\hline & 34.50 & 0.50 & 33.33 & 21.35 & 0.91 & 1.23 & 1.28 & 0.22 & 1.86 \\
\hline & 71.64 & 0.50 & 33.33 & 21.35 & 1.07 & 0.59 & 1.66 & 0.19 & 1.64 \\
\hline & 93.01 & 0.50 & 33.33 & 21.35 & 1.16 & 0.46 & 1.69 & 0.16 & 1.84 \\
\hline \multirow[t]{4}{*}{ C100-3-3-fck-50 } & 0 & 0.50 & 33.33 & 31.35 & 1.14 & & & 0.28 & 2.11 \\
\hline & 36.68 & 0.50 & 33.33 & 31.35 & 1.35 & 1.16 & 1.14 & 0.17 & 2.16 \\
\hline & 79.55 & 0.50 & 33.33 & 31.35 & 1.62 & 0.53 & 1.25 & 0.12 & 2.19 \\
\hline & 90.40 & 0.50 & 33.33 & 31.35 & 1.68 & 0.47 & 1.30 & 0.12 & 2.93 \\
\hline \multirow[t]{4}{*}{ C100-5-2-fck-50 } & 0 & 0.50 & 20.00 & 21.35 & 0.79 & & & 0.30 & 2.52 \\
\hline & 30.54 & 0.50 & 20.00 & 21.35 & 0.87 & 2.47 & 1.13 & 0.24 & 2.41 \\
\hline & 61.00 & 0.50 & 20.00 & 21.35 & 0.97 & 1.24 & 1.29 & 0.21 & 2.22 \\
\hline & 81.66 & 0.49 & 20.32 & 21.01 & 1.02 & 0.90 & 1.50 & 0.21 & 1.92 \\
\hline \multirow[t]{4}{*}{ C100-5-3-fck-50 } & $0(*)$ & 0.20 & 20.32 & 30.86 & 1.14 & & & 0.23 & 2.09 \\
\hline & 39.56 & 0.49 & 20.32 & 30.86 & 1.30 & 1.86 & 1.29 & 0.19 & 2.36 \\
\hline & 72.49 & 0.49 & 20.32 & 30.86 & 1.45 & 1.02 & 1.36 & 0.16 & 2.11 \\
\hline & 96.74 & 0.49 & 20.32 & 30.86 & 1.55 & 0.76 & 1.47 & 0.15 & 2.35 \\
\hline \multirow[t]{3}{*}{ C125-5-3-fck-50 } & $0(*)$ & 0.16 & 25.00 & 25.08 & 0.92 & & & 0.31 & 2.46 \\
\hline & 96.97 & 0.40 & 25.00 & 25.08 & 1.31 & 0.60 & 1.71 & 0.20 & 1.69 \\
\hline & 97.92 & 0.40 & 25.00 & 25.08 & 1.31 & 0.60 & 1.73 & 0.20 & 1.69 \\
\hline \multirow[t]{3}{*}{ C160-6-3-fck-50 } & $0(*)$ & 0.31 & 28.09 & 19.58 & 0.71 & & & 0.40 & 3.00 \\
\hline & 74.75 & 0.31 & 28.09 & 19.58 & 0.97 & 0.69 & 1.79 & 0.29 & 1.82 \\
\hline & 98.50 & 0.31 & 28.09 & 19.58 & 1.05 & 0.52 & 1.91 & 0.26 & 1.77 \\
\hline
\end{tabular}


Portolés Jl, Romero ML*, Bonet JL and Filippou FC, Experimental study of high strength concrete-filled circular tubular columns under eccentric loading, Journal of Constructional Steel Research 2011; 67 (4) : 623-633. 